\title{
The Evolution of Secularization: Cultural Transmission, Religion and Fertility Theory, Simulations and Evidence
}

\author{
Ronen Bar-El \\ Department of Economics and Management \\ The Open University, Israel \\ Teresa Garcia-Muñoz \\ Department of Quantitative Methods \\ University of Granada \\ Granada, Spain \\ Shoshana Neuman* \\ Department of Economics \\ Bar-Ilan University, Ramat-Gan, Israel; \\ CEPR, London; IZA, Bonn \\ Yossef Tobol \\ Inter-Disciplinary Department of Social Sciences \\ Bar-Ilan University, Ramat-Gan, Israel
}

\begin{abstract}
This study presents an evolutionary process of secularization that integrates a theoretical model, simulations, and an empirical estimation that employs data from 32 countries (included in the International Social Survey Program: Religion II - ISSP, 1998). Following Bisin and Verdier (2000, 2001a), it is assumed that cultural/social norms are transmitted from one generation to the next one via two venues: (i) direct socialization - across generations, by parents; and (ii) oblique socialization - within generations, by the community and cultural environment. This paper focuses on the transmission of religious norms and in particular on the 'religious taste for children'. The theoretical framework describes the setting and the process leading to secularization of the population; the simulations give more insight into the process; and 'secularization regressions' estimate the effects of the various explanatory variables on secularization (that is measured by rare mass-attendance and by rare-prayer), lending support to corollaries derived from the theory and simulations. The main conclusions/findings are that (i) direct religious socialization efforts of one generation have a negative effect on secularization within the next generation; (ii) oblique socialization by the community has a parabolic effect on secularization; and (iii) the two types of socialization are complements in 'producing' religiosity of the next generation.
\end{abstract}

Keywords: cultural transmission, religion, fertility, secularization, ISSP

*Corresponding author. Email: neumans@mail.biu.ac.il

Thanks are due to two referees for very helpful comments and suggestions.

Shoshana did part of this study during her stay at IZA (summer 2009). She would like to thank the IZA Institute for its hospitality and excellent research facilities. In particular, thanks are due to Margard Ody, IZA's Information Manager, for providing the numerous articles used for the literature review.

Ronen and Yossi would like to thank Dr. Smadar Shatz for her help Maple programming.

Teresa García-Muñoz acknowledges financial support from the MCI (SEJ2007-62081/ECON), Junta de Andalucía-Excelencia (P07.SEJ.02547) and Instituto de la Mujer (2007 I+D+I/031). 


\section{Introduction and motivation}

It is now well established that an individual's norms, tastes and beliefs are, to a large extent, determined during his young formative years. Following Bisin and Verdier (2000, 2001a), these norms and values are labeled here as 'culture', and the transmission of the norms across generations as 'cultural transmission'. The experiences and impressions during childhood and adolescence have a lasting effect on behaviour via two parallel processes: (i) social interactions across generations within the family, and (ii) within generations by the local cultural and social environment (e.g. schools, religious organizations, or neighborhood composition). These two venues are referred to as 'direct vertical socialization' versus 'oblique socialization' (terminology used by Cavalli-Sforza and Feldman, 1981).

This paper relates to one specific component of 'culture', namely 'religiosity', which is expressed by religious norms, beliefs and behavior. The process of intergenerational transmission of 'religiosity' will be described by the (i) diffusion of religious beliefs that affect religious practice (evidenced by attendance of church services ${ }^{2}$ and private prayer); and (ii) passing on the religious 'taste for children' that determines fertility among the 'religious' sub-population, and consequently, the religious make-up of the population. These two elements are the focus of this study.

The great majority of studies on this topic (reviewed in the next section) are empirical. They are quite narrow in the sense that they do not provide a systematic full description of the religious transmission process, fertility decisions and the resulting changes in the religious/secular composition of the population. This paper aims at filling this gap by presenting a systematic theoretical model of the cultural transmission of religious norms and beliefs and their effect on reproductive behavior, and consequently, on

\footnotetext{
${ }^{1}$ The Merriam-Webster dictionary defines culture as: "a: the integrated pattern of human knowledge, belief, and behavior that depends upon man's capacity for learning and transmitting knowledge to succeeding generation; b: the customary beliefs, social forms, and material traits of a racial, religious or social group, also: the characteristic features of everyday existence (as diversions or a way of life) shared by people in a place or time."

${ }^{2}$ The term 'church' is a generic term for the place of religious worship (synagogue, in the Jewish religion; mosque, in the Moslem faith, etc.)
} 
secularization $^{3}$. It is an evolutionary dynamic model that is constructed on the foundations of Bisin and Verdier (2000, 2001a). Hypotheses will be derived based on the theoretical model and simulations. Data from 32 countries, collected within the framework of the International Social Survey Program (ISSP): Religion II (1998), will then be used to support the theory and simulations with empirical evidence. The ISSP is an ongoing endeavour devoted to cross-country research on national attitudes. The data covers the European and Australian continents and North America ${ }^{4}$. The African continent is excluded and South America and Asia are represented by a small number of countries (Chile, Japan, Israel and the Philippines). The research is therefore pertaining to Europe, North-America and Australia, and a few other countries. The ISSP includes questions on attitudes, beliefs and opinions on various issues, as well as numerous questions regarding individuals' socio-economic and religious behaviours. It includes also retrospective data on 'religiosity' of the previous generation: (i) the religious denomination of the respondent when he was a child, as well as his father's and mother's; and (ii) the frequency of maternal and paternal church attendance, as well as the respondent's church participation when he was 12 years old. These variables are crucial for the analysis of the intergenerational transmission of 'religiosity'. Information on the religious denomination of the spouse is also included.

The next section presents a literature overview. Section 3 presents the theoretical model, followed by simulations that detect the dynamic changes in the religious make-up (shares of secular/religious) caused by changes in the model's core parameters. Corollaries derived from the model and simulations are also presented. The fifth section presents

\footnotetext{
${ }^{3}$ The concept 'secularization' has been used in the literature to refer to diverse aspects such as: (i) differentiation of the major institutions of society (law, politics, economy, education, etc.) from the influence of religion; (ii) rationalization (Weber, 1930); (iii) demystification of all spheres of life; (iv) less adherence to religious acts such as attendance of religious services and prayer. We refer only to this last sub-part of the term 'secularization'. Sommerville (1998) sorted out the different aspects of secularization and divided them into two categories: (i) those presented in terms of processes (like decline, differentiation, disengagement, rationalization); or (ii) in terms of aspects of life or levels of analyses (structural, cultural, organizational, individual). We refer to 'secularization' as a decline in individual religious practice. Tschannen (1991) provides an inventory of the elements of classic theories of secularization. See also Swatos and Christiano (1999) for a comprehensive review of the secularization theory and debate.

${ }^{4}$ An interesting point relating to this is that historically, secularization finds its roots in the enlightenment movement of the $17^{\text {th }}$ and $18^{\text {th }}$ century in the predominantly Christian Europe and North America.
} 
empirical evidence that lends support to the conclusions of the theoretical model and simulations. The last section summarizes and concludes.

\section{Literature overview}

Cultural transmission has been studied by several disciplines of the social sciences: e.g. anthropology, sociology, social psychology, as well as evolutionary biology. Early studies on cultural transmission include, among many others: Cavalli-Sforza and Feldman, (1973, 1981); Hoge et al., (1982); Boyd and Richerson, (1985). Recently, economists have also realized that systematic variation in culture and religion matters to important economic phenomena, such as: educational attainments (Mulligan, 1999; Landes, 2000; Black et al., 2005; Fan, 2008); labor force participation (Fernandez and Fogli, 2009); occupation (Long and Ferrie, 2005); income (Solon, 1992; Mulligan, 1997); marriage and inter-faith marriage (Bisin et al., 2004); fertility (Blau, 1992; Fernandez and Fogli, 2006, 2009; Neuman, 2007; Brañas-Garza and Neuman, 2007); as well as attitudes which affect the labor market and other economic and social performance, such as attitudes of trust and risk (Dohmen et al., 2006) and attitudes of cooperation (Cipriani et al., 2007). It follows that variations in culture may be responsible for observed differences in socio-economic outcomes and should therefore be incorporated into the analysis of intermarriage, fertility, labor market behavior, educational attainments, secularization, etc.

Our paper focuses on religious behaviour (secularization) that evolves from intergenerational religious transmission. The process of religious transmission includes the (i) diffusion of religious beliefs; and (ii) passing on the religious 'taste for children' that determines fertility. These two elements are central in this study. (i) Azzi and Ehrenberg (1975), Neuman (1986) and Iannaccone (1990) suggested to follow the human capital approach to study the accumulation of an individual's 'religious capital ${ }^{5}$. The accumulation of an individual's 'religious capital' starts at childhood when the parents pass on religious knowledge and attitudes to their children, and when the child is exposed

\footnotetext{
5 'Religious capital' is a variant of the broader concept of 'human capital'. de la Croix and Michel (2002) relate to human capital accumulation models in which social norms are transmitted from one generation to the next one.
} 
to religious practice at school, at church and at the neighbourhood he lives in. A positive empirical relationship between the intensity of exposure to religious conduct during childhood and the individual's current religiosity has been documented in the literature (e.g., Hoge et al., 1982; Clark and Worthington, 1987; Cornwall, 1988; Ozorak, 1989; Erickson, 1992; Thomson et al., 1992; Hayes and Pittelkow, 1993; Brañas-Garza and Neuman, 2006). Sherkat and Wilson (1995) used the concept 'adaptive preferences' and claimed that socialization through childhood religious practice creates preferences upon which later religious choices will be made. Shy (2007), who presented a dynamic theoretical model of religious conformity and conversion, claimed that religious education by the parents and by the church enhances religious conformity. It follows that more exposure to childhood religious socialization will decrease the likelihood of secularization later on in life. Gender differences in the religious transmission process have also been recognized (e.g., Beit-Hallahmi, 1997; Brañas-Garza and Neuman, 2004).

Parents have a technology for transmitting religious values to their children. Families that are more homogeneous with respect to their religious beliefs are endowed with a more productive technology to socialize children to such beliefs. The same effort exerted by the parent will therefore yield better results in homogamous same-faith families. Moreover, parents are not only actively instilling children with preferences and beliefs similar to their own; they are also serving as role-models their children imitate. A homogamous family in which the two role-models behave by similar rules and beliefs facilitates an easier and more efficient imitation process. In the same vein, if the founding couple do not share the same faith, they are less likely to pass on a religious legacy due to disagreement about religious rules. In fact, intermarriage signals that religion has lost its prime value and importance ${ }^{6}$.

\footnotetext{
${ }^{6}$ Obviously, this is only one explanation for the higher 'value' of religiously homogamous families, an explanation that emphasizes the link between marriage choices and the socialization of children to their parents' religious beliefs and norms. As a consequence, individuals are willing to exert effort to segregate into a restricted marriage pool in which they are more likely to meet prospective spouses of the same religious faith. Marriage choices are therefore motivated (also) by the desire to socialize children and will result in assortative marriage pairs along religious lines. There might be positive assortative mating also along lines of other attitudes and beliefs. Dohmen et al. (2006) investigated whether there was evidence for assortative mating based on risk and trust attitudes and did not find such evidence.
} 
Diffusion of religious norms and behavior is affected by parental religious inputs via 'direct vertical socialization', but also via 'oblique socialization' by the religious environment. A closely related topic is the relationship between the religious pluralism (diversity) and religiosity (adherence) of the population.

The literature offers two conflicting 'theories' and presents opposite empirical results. The long-standing 'demand-side' views (also referred to as the 'secularization hypothesis', presented mainly by sociologists) expect more secularization in more religiously pluralistic states. At the other end, the 'supply-side' or 'market theory' (presented by economists) predicts less secularization (more religious adherence) in countries that are more religiously-diverse ${ }^{7}$.

The demand-side theory claims that in countries with a diversity of religious denominations, individuals are exposed to a variety of religion products and this might weaken their ties with the religion they were raised in (e.g. Kelley, 1977; Sherkat, 1991, among many others). The process of disaffiliation is magnified by intermarriage. If there is a dominant denomination, a high proportion of marital unions will bring together two people with the same religious affiliation. On the other hand, in a multi-religion country there are higher prospects of intermarriage. Intermarriage reduces the probability of religious affiliation for the offspring and increases the likelihood of disaffiliation for the spouses (Voas, 2003).

The supply-side approach treats churches as firms producing a mix of valuable products (e.g. Iannaccone, 1991). If religious markets function like other markets, then a greater diversity of religions available in a country is said to promote greater competition, and hence, a higher quality religion product. Religiously pluralistic markets would stimulate churches to produce religious services well adapted to the needs of religious consumers,

\footnotetext{
${ }^{7}$ Following our theoretical model we focus on the effect of religious diversity (pluralism) on secularization. The extensive literature on the 'demand side' and 'supply side' theories of religiosity is much broader and looks at the relationship between religiosity and a battery of potential explanatory variables, such as: economic development, urbanization (McCleary and Barro, 2006), the existence of a state religion (Barro and McCleary, 2005), and public spending (Gill and Lundsgaarde, 2004; Franck and Iannaccone, 2009; Hungerman, 2009).
} 
thereby increasing 'religious consumption' (e.g. church attendance) (examples of such studies that also presented evidence on the suggested positive relationship include: Finke and Stark 1988, 1989; Iannaccone, 1991; Finke, 1992). An often cited example for the positive relationship between religious pluralism and religiosity is the case of the United States, which among the industrialized nations, has both the highest levels of religious pluralism and one of the highest rates of church attendance (e.g. Warner, 1993). Thus, according to the 'religious market theory', more religious diversity stimulates greater religious participation (less secularization). Breault (1989a, 1989b) and Olsen (1999) loudly criticized the 'religious market theory', and in particular the findings of Finke and Stark (1988) who claimed a positive link between pluralism and participation in the US. They 'reassessed' the findings for the US and arrived at a negative relationship.

It might well be the case that demand and supply forces are both at work simultaneously and the final outcome is determined by the more dominant force. Moreover, could be that up to some level of religious pluralism, demand forces dominate and dictate a negative relationship between religious diversity and religious practice, whereas from that point onwards supply effects take over, leading to a positive association between religious diversity and religious performance.

(ii) The process of transmitting the 'taste for children' is less obvious and probably more complex. Since economists typically assume that preferences are stable and beyond the scope of their analysis, it is not surprising that relatively little work has been done by economists on the cultural transmission of preferences for children (which affect fertility and differ along the lines of ethnicity, social class, religion, etc.). In several studies examining immigrants' fertility patterns it has been shown that country of origin matters (Blau, 1992; Guinnane et al., 2006; Fernandez and Fogli, 2009; Booth and Kee, 2009). It has been argued that different countries possess different values and norms regarding the appropriate roles for women in society, and what is the ideal family size. These preferences and beliefs are transmitted by the parents during childhood, and hence, where a woman's parents were born matters even if the examined women had left their country of origin and now share the same economic incentives, markets and institutions. Murphy and Kundsen (2002), Booth and Kee (2009) and Fernandez and Fogli (2006), addressed 
also the effect of the number of siblings in the family of origin on fertility. They found positive significant effects for Sweden, Britain and the US.

How does religiosity in the country of origin and in the family where the woman grew up affect her taste for children and consecutively her fertility? ${ }^{8}$ The economics literature does not provide a clear-cut answer to this question. However, it has often been claimed that there is a positive relationship between fertility and current religiosity. Research on the relationship between current religiosity and fertility is mainly empirical and has taken two directions: one examined differences in fertility between religions that coexist in the same country (e.g., Lehrer, 1996; Morgan et al., 2002; Borooah, 2004; Schellekens and van Poppel, 2006); and a second, more limited line, linked differences in fertility within a given religion to the individual's intensity of religious practice (e.g., Mosher and Hendershot, 1984; Neuman and Ziderman, 1986; Sander, 1992; Amin et al., 1997; Brañas-Garza and Neuman, 2007). These two lines are intertwined - intensive religious practice will influence fertility only if the religion has a pro-natalist ideology. The natural explanation for the positive relationship between religiosity and fertility was that pronatalist religions have an integral built-in preference for children (both directly and also indirectly via the illegal use of contraceptives and abortion). It follows that more religious parents have more children. If we combine this result with the findings cited above regarding the positive relationship between fertility and the number of siblings in the family of origin, we can speculate that the 'taste for children' is passed on from mother to daughter, and daughters of more religious mothers (who have more siblings) will also have more children. However, in empirical studies that examined Spanish and Italian Catholic women, it was found that daughters of ultra religious mothers (who participated in church services at least once a week and most probably had preferences for large families) had less children (by about 0.7 children) compared to women who were raised by less religious mothers (Neuman, 2007; Brañas-Garza and Neuman, 2007). It therefore

\footnotetext{
${ }^{8}$ Obviously, a woman's fertility is affected by a large number of other factors as well. Economists focus especially on investments in human capital, and on wealth and income that result from human capital accumulation (Becker, 1960; Becker and Lewis, 1973; Becker and Tomes, 1976; Becker and Barro, 1988; Becker et al., 1990; Hanushek, 1992; and Ermisch, 2003). These factors have to be controlled when the effect of religious transmission is examined. Recently economists also referred to non-economic motives, such as social aspirations (Tournemaine, 2008)
} 
appears that the process of intergenerational transmission of the 'taste for children' is more complex and not necessarily positively monotonic.

\section{The theoretical model: Intergenerational transmission of religious norms and the evolutionary process of secularization}

To describe the dynamics of the secular/religious ratio within a country's population, we utilize Bisin and Verdier's (2001a) framework to portray cultural transmission of religious norms and its effect on fertility patterns, and consequently on the religious make-up (i.e. the shares of religious/secular residents) of the next generation.

Consider a society that consists of two types of sub-populations: religious $(r)$, and secular $(s)^{9}$. In the empirical section that follows we will define 'secular' and 'religious' in terms of frequency of church attendance and frequency of prayer habits ${ }^{10}$.

The individuals in this society operate in a two period overlapping generation world: each individual belongs to a family where she/he is a child in her first period, and may become a parent in her/his second period $t$, in which she is economically active. Each family has one parent who is the decision maker of the household. At the outset of the second period each individual of type $i, i \in\{r, s\}$ gives birth to $n_{t}^{i}$ offspring. Therefore, each family of type $i, i \in\{r, s\}$, consists of a parent and $n_{t}^{i}$ children. A parent of type $i$, living at time $t$, derives utility from the number of children, $n_{t}^{i}$, as well as from their type (religious/secular). The utility associated with children is defined by $k^{i} f^{i}\left(n_{t}^{i}\right)$ where $k^{i}$ is the 'taste for children' of parents of type $i$. In addition we assume that the marginal utility from the number of children is positive and diminishing, that is, $\left(f^{i}\right)^{\prime}>0,\left(f^{i}\right)^{\prime \prime}<0$ and $\lim _{n \rightarrow 0}\left(f^{i}(n)\right)^{\prime}=\infty, \lim _{n \rightarrow \infty}\left(f^{i}(n)\right)^{\prime}=0$. It is also assumed that

\footnotetext{
${ }^{9}$ Defining secular is normally done relative to some definition of religious. As Bailey (1998) puts it: "Secular is really quite easy to define! Its meaning keeps changing yet remains consistent. It is always means, simply, the opposite of "religious" - whatever that means" (1998: 18).

${ }_{10}$ Obviously, there are alternative measures for the identification of secular/religious individuals. For instance, measures that examine beliefs (in: God, afterlife, miracles, etc.). The advantage of the church attendance measure is that it is quantifiable and objective. We also experimented with another quantitative measure that related to prayer ("how many times a day do you pray?" ranging from 'never' (category 1) to 'several times a day (category 11)). The empirical results based on each of these two types of religious practice were very similar.
} 
$f(0)=0^{11}$. Judaism, Christianity and Islam all advocate high fertility and limit the use of birth control measures and abortions, it is therefore assumed that a religious parent has a stronger 'taste for children' than a secular one, i.e., $k^{r}>k^{s}$ meaning that ceteris paribus religious individuals will have more children ${ }^{12}$.

All children are born without defined preferences or cultural/religious traits and are first exposed to their parent's traits. We assume that each parent has a strong preference for having children who share his own traits. Motivated by this form of paternalistic altruism (or 'imperfect empathy'), a parent always attempts to socialize her children to her own preference traits (Bisin and Verdier, 2001a, 2001b; Bisin et al., 2004). We denote the utility derived by a parent of type $i$ from a child which inherited her level of religiosity by $V^{i i}$ and the utility which a parent of type $i$ derives from a child who did not inherit her type of religiosity by $V^{i j}$, where $V^{i i}>V^{i j}>0$. The difference $\Delta V^{i} \equiv V^{i i}-V^{i j}$ represents the 'relative intolerance' defined as the perceived utility gains that a parent of religious group $i$ derives from offspring of religion level $i$ rather than $j$ (Bisin et al., 2004: 618). A parent can affect her children's traits by socializing them to her own values. A successful socialization process is driven by two factors: the parent's 'direct socialization effort' and the neighborhood or 'oblique effect'. The direct parental effort has a success probability of $d_{t}^{i}\left(0 \leq d_{t}^{i} \leq 1\right)$. If a child was not successfully socialized by her parent, which occurs with probability $\left(1-d_{t}^{i}\right)$, she will pick up a trait randomly via the neighborhood effect (oblique socialization) ${ }^{13}$. The trait $i$ will be picked-up with probability $q_{t}^{i}$ (where $q_{t}^{i}$ is the fraction of individuals with trait $i$ ), and a trait $j \neq i$ will be

\footnotetext{
${ }^{11}$ We differ from Bisin and Verdier (2001a) by assuming, in line with Becker's seminal contributions, that individuals derive utility from raising offspring.

${ }^{12}$ Religious people are obligated to follow the command: "Be fruitful and increase in number; fill the earth and subdue it." (Genesis 1:28).

${ }^{13}$ Note that in this model we are not considering the individual's choices of location. Although, in many cases, different sectors segregate themselves by creating closed communities thus preventing their offspring from encounters with other sectors that could result in socialization to the different sector. It is assumed therefore that $q_{t}^{i}$ is exogenous at each period, i.e., the parent does not choose a neighborhood with an optimal religious mix of residents. On choice of locations, see Buchanan and Faith (1987) and Alesina and Spolaore (1997). Within the framework of manufacturing, see Krugman (1991) on the choice of location of firms.
} 
picked-up with probability $\left(1-q_{t}^{i}\right)$. It is further assumed that the probability of a child to be socialized into a specific trait is independent of her siblings' traits.

By the law of large numbers, the expected utility that a parent of type $i$ has from a child's type/religiosity at time $t$ is:

(1) $E\left(V_{t}^{i}\right) \equiv\left(d_{t}^{i}+\left(1-d_{t}^{i}\right) q_{t}^{i}\right) V^{i i}+\left(1-d_{t}^{i}\right)\left(1-q_{t}^{i}\right) V^{i j} \equiv\left(\left[d_{t}^{i}+\left(1-d_{t}^{i}\right) q_{t}^{i}\right] \Delta V^{i}+V^{i j}\right)$.

The utility associated with the offspring's type/religiosity is linear in the number of children and is: $n_{t}^{i} E\left(V_{t}^{i}\right)$.

Raising children implies costs. The cost of raising $n_{t}^{i}$ children, by a parent with trait $i$, is denoted by $\phi^{i}\left(n_{t}^{i}\right)$ and assumed to be linear in the number of children, i.e.,: $\left(\phi^{i}\left(n_{t}^{i}\right)\right)^{\prime}>0,\left(\phi^{i}\left(n_{t}^{i}\right)\right)^{\prime \prime}=0, \phi^{i}(0)=0,\left(\phi^{i}(0)\right)^{\prime}=0{ }^{14}$. It is also assumed that $\phi^{i}\left(n_{t}^{i}\right)$ and $\left(\phi^{i}\left(n_{t}^{i}\right)\right)^{\prime}$ are continuous functions for $n>0$.

Direct parental socialization is also costly. It is assumed that parents with trait $i$ devote to each of their children the same direct socialization effort. The cost of direct socialization per child is denoted by $\psi^{i}\left(d_{t}^{i}\right)$,

where: $\left(\psi^{i}\left(d_{t}^{i}\right)\right)^{\prime}>0,\left(\psi^{i}\left(d_{t}^{i}\right)\right)^{\prime \prime}>0, \psi^{i}(0)=0,(\psi(0))^{\prime}=0$ and $\lim _{d_{t}^{i} \rightarrow 1} \psi^{i}\left(d_{t}^{i}\right)=\infty$. That is, the marginal cost of socializing a child is positive and increasing. It is further assumed that $\psi^{i}\left(d_{t}^{i}\right)$ and $\left(\psi^{i}\left(d_{t}^{i}\right)\right)^{\prime}$ are continuous functions.

Note that we are assuming that the parent's socialization costs are linear with respect to the number of children, i.e., there are no returns to scale within a family. The cost of socializing $n$ children is therefore $n_{t} \psi^{i}\left(d_{t}^{i}\right)$. It could be claimed that within a family, socialization has the nature of a public good since messages and values are delivered to the family as a whole. However, on the other hand, there is what we may call a 'rotten

${ }^{14}$ See for example Becker and Lewis (1973) and Becker and Barro (1988). 
kid' effect. If despite the socialization process one child switches to the other trait, he may become the 'rotten apple' in the family's barrel. It is therefore supposed that negative and positive externalities of the socialization processes net out each other and as a result there are no returns to scale.

Furthermore, we assume that the cost of rearing children and the cost of socialization are separable and additive, hence the total cost of rearing children and socializing them is $\phi^{i}\left(n_{t}^{i}\right)+n_{t}^{i} \psi^{i}\left(d_{t}^{i}\right)^{15}$

Individuals of trait $i$ derive utility from consumption at time $t, c_{t}^{i}$ whose unit price is set equal to 1 .

The utility function of a representative parent who lives at time $t$ and belongs to type $i$, is given by:

$$
u_{t}^{i}\left(n_{t}^{i}, V_{t}^{i}\right)=k^{i} f^{i}\left(n_{t}^{i}\right)+n_{t}^{i} E\left(V_{t}^{i}\right)+c_{t}^{i} .
$$

Each household is endowed with the same initial wealth $W$, hence the budget constraint facing individual $i$ of trait $t$ is:

$$
\phi^{i}\left(n_{t}^{i}\right)+n_{t}^{i} \psi^{i}\left(d_{t}^{i}\right)+c_{t}^{i}=W
$$

Each parent maximizes her utility subject to the budget constraint by choosing the number of children, $n_{t}^{i}$, and the socialization effort per child, $d_{t}^{i}$. The first order conditions are given by:

$$
\begin{aligned}
& \frac{\partial u_{t}^{i}}{\partial n_{t}^{i}}=k^{i}\left(f^{i}\left(n_{t}^{i}\right)\right)^{\prime}+E\left(V_{t}^{i}\right)-\left(\left(\phi^{i}\left(n_{t}^{i}\right)\right)^{\prime}+\psi^{i}\left(d_{t}^{i}\right)\right)=0 \\
& \frac{\partial u_{t}^{i}}{\partial d_{t}^{i}}=n_{t}^{i}\left[\left(1-q_{t}^{i}\right)\left(V^{i i}-V^{i j}\right)\right]-n_{t}^{i}\left(\psi^{i}\left(d_{t}^{i}\right)\right)^{\prime}=0 .
\end{aligned}
$$

\footnotetext{
${ }^{15}$ With this assumption we follow other scholars, see for example Galor and Moav (2002) and Galor and Weil (2000).
} 
From equations (4) and (5) we obtain the optimal number of offspring and the optimal socialization effort per child, for an individual of type $i$ at time $t$ :

$$
n_{t}^{i}=n_{t}^{i}\left(V^{i i}, V^{i j}, q_{t}^{i}, k^{i}\right), \quad d_{t}^{i}=d_{t}^{i}\left(V^{i i}, V^{i j}, q_{t}^{i}, k^{i}\right)^{16}
$$

In the following propositions we will verify that the model predicts that: when some degree of heterogeneity exists within the population, a parent prefers to have children and directly socializes them to her own values.

Proposition 1: $0 \leq d_{t}^{i}\left(q_{t}^{i}\right)<1 \forall q_{t}^{i} \in[0,1]$.

Proof: From equation (5) we get that $0<d_{t}^{i}(0)<1$ and $d_{t}^{i}(1)=0$. As $\left(\psi^{i}\left(d_{t}^{i}\right)\right)^{\prime \prime}>0$, and by the continuity of $\psi^{\prime}\left(d_{t}^{i}\left(q_{t}^{i}\right)\right)$ for $q_{t}^{i} \in[0,1]$ the proposition is proven. Equation (5) indicates that the socialization effort per child is not related to the number of offspring, due to our earlier assumption on the linearity of socialization costs with respect to the number of children. Equation (5) also indicates that in the extreme case where $q_{t}^{i}=1$, the parent does not make any direct socialization effort since the probability that an offspring's type will be other than the parent's is zero. However, when $q_{t}^{i}<1$ a parent directly socializes her offspring since she prefers offspring who inherent her own trait.

From equation (4) we obtain that a parent always prefers a positive number of offspring. Formally:

Proposition 2: $n_{t}^{i}=n_{t}^{i}\left(V^{i i}, V^{i j}, q_{t}^{i}, k^{i}\right)>0$ for every $q_{t}^{i} \in[0,1]$.

\footnotetext{
${ }^{16}$ See appendix A for derivation of the second order conditions for maximization.
} 
Proof: From proposition 1 we have concluded that $\psi^{i}\left(d_{t}^{i}\left(q_{t}^{i}\right)\right)$, as well as $E\left[V_{t}^{i}\right]$, are finite for $q_{t}^{i} \in[0,1]$. By the assumptions on $\left(\phi^{i}\left(n_{t}^{i}\right)\right)^{\prime}$ and $\left(f^{i}\left(n_{t}^{i}\right)\right)^{\prime}$ we conclude that a parent always chooses a positive number of children.

The solution to the parent's 'direct socialization effort' is given solely by equation (5). Given that solution, equation (4) shows that a parent derives positive and finite expected utility from her offspring's trait and bears finite and positive costs from directly socializing the offspring and rearing them. Nevertheless, her marginal utility from rearing children, when she has none, is infinite; therefore she always prefers to have offspring.

\subsection{Comparative statics}

This sub-section examines how the optimal levels of the two decision variables $\left(n_{t}^{i}\right.$ and $\left.d_{t}^{i}\right)$ are affected by changes in the exogenous variables of the model $\left(q_{t}^{i}\right.$ and $\left.k^{i}\right)$.

\subsubsection{A change in $q_{t}^{i}$ :}

Fully differentiating the first order conditions with respect to $q_{t}^{i}$, leads to the following:

$$
\left(\begin{array}{ll}
\Omega_{11} & \Omega_{12} \\
\Omega_{21} & \Omega_{22}
\end{array}\right)\left[\begin{array}{c}
\frac{\partial n_{t}^{i}}{\partial q_{t}^{i}} \\
\frac{\partial d_{t}^{i}}{\partial q_{t}^{i}}
\end{array}\right]=\left(\begin{array}{c}
-\left(1-d_{t}^{i}\right) \Delta V^{i} \\
n_{t}^{i} \Delta V^{i}
\end{array}\right)
$$

By Cramer's Law we obtain:

$$
\frac{\partial n_{t}^{i}}{\partial q_{t}^{i}}=\frac{-\left(1-d_{t}^{i}\right) \Delta V^{i} \Omega_{22}}{\Omega}>0
$$

$$
\frac{\partial d_{t}^{i}}{\partial q_{t}^{i}}=\frac{n_{t}^{i} \Delta V^{i} \Omega_{11}}{\Omega}<0 .
$$


From equations (1) and (4) we see that the marginal benefit from an additional offspring increases as the expected value of the trait rises, while the marginal cost remains constant. Therefore the number of offspring of a parent of type $i$ increases with the share of her trait among the general population ${ }^{17}$. From equation (5) we see that the marginal benefit from directly socializing offspring to trait $i$ is decreasing with the share of the trait among the general population, as the expected trait value increases due to oblique socialization. It follows that the direct socialization effort to trait $i$ is decreasing with the share of the trait among the general population.

\subsubsection{A change in $k^{i}$}

The 'taste for children' effect is obtained by fully differentiating the first order conditions with respect to $k^{i}$ :

$$
\left(\begin{array}{cc}
\Omega_{11} & 0 \\
0 & \Omega_{22}
\end{array}\right)\left[\begin{array}{l}
\frac{\partial n_{t}^{i}}{\partial k^{i}} \\
\frac{\partial d_{t}^{i}}{\partial k^{i}}
\end{array}\right]=\left(\begin{array}{c}
-f^{\prime}\left(n_{t}^{i}\right) \\
0
\end{array}\right)
$$

By applying Cramer's Law to equation (10) we obtain:

$$
\frac{\partial n_{t}^{i}}{\partial k^{i}}=-\frac{f^{\prime}\left(n_{t}^{i}\right) \Omega_{22}}{\Omega}>0
$$

\footnotetext{
${ }^{17}$ This result also leads to the prediction that ethnic/religious minorities will have fewer children in the host country than in their country of origin. This prediction is in line with the 'minority-group-status' hypothesis suggested by Sociologists (e.g. Knodel, 1974) who argued that minority groups who had high fertility rates in their countries of origin tend to adopt local practices of reducing family size. An often cited example relates to Jews in the US who have birth rates that are even lower than the US average. On the other hand, Mormons in the US have high birth rates (much higher than the country average; Heaton, 1986 and Lehrer, 1996), most probably because they live in closed and isolated communities and therefore enjoy a very high $q$.
} 


$$
\frac{\partial d_{t}^{i}}{\partial k^{i}}=0
$$

where $\Omega=u_{t}^{i}\left(d_{t}{ }^{i}, n_{t}{ }^{i}\right){ }^{18}$ From equation (11) and (12) we see that an increase in $k^{i}$ has a positive effect on the number of children but nevertheless does not have any effect on the direct socialization effort.

\subsection{The evolutionary dynamics of secularization}

The main goal of this study is to present and explain the evolution of secularization (increase in the share of seculars, or the probability to become secular). This sub-section looks at the dynamics of the secularization process that evolves from the model. To gain more insight into this process, several simulations are performed in order to uncover the effects of the various model's variables on secularization. These simulations lead to testable hypotheses, tested using data from a battery of countries.

The ratio of 'seculars' at time $t+1, q_{t+1}^{s}$ is defined by:

$$
\begin{aligned}
q_{t+1}^{s}= & \frac{n_{t}^{s} N_{t}^{s}\left(d_{t}^{s}+\left(1-d_{t}^{s}\right) q_{t}^{s}\right)+n_{t}^{r} N_{t}^{r}\left(1-d_{t}^{r}\right) q_{t}^{s}}{n_{t}^{s} N_{t}^{s}+n_{t}^{r} N_{t}^{r}} \\
& =\frac{v_{t} q_{t}^{s}\left(d_{t}^{s}+\left(1-d_{t}^{s}\right) q_{t}^{s}\right)+\left(1-v_{t}\right)\left(1-q_{t}^{s}\right)\left(1-d_{t}^{r}\right) q_{t}^{s}}{v_{t} q_{t}^{s}+\left(1-v_{t}\right)\left(1-q_{t}^{s}\right)}
\end{aligned}
$$

where $N_{t}^{i}$ is the number of people with trait $i$ at time $t, q_{t}^{s} \equiv \frac{N_{t}^{s}}{N_{t}^{s}+N_{t}^{r}}$ is the share of secular among the general population at time $t, n_{t}^{i}$ is the number of children a parent with trait $i$ has, and $v_{t} \equiv \frac{n_{t}^{s}}{n_{t}^{s}+n_{t}^{r}}$ is the ratio of children of secular parents within the total number of children at time $t$. By proposition $2 v_{t}>0 \forall q_{t}^{s} \in[0,1]$. From equation (13)

\footnotetext{
${ }^{18}$ See also appendix.
} 
we calculate the change in the share of seculars within the total population, from one period to the next one: ${ }^{19}$

$$
\dot{q}_{t}^{s}=\frac{q_{t}^{s}\left(1-q_{t}^{s}\right)\left(v_{t} d_{t}^{s}-d_{t}^{r}\left(1-v_{t}\right)\right)}{v_{t} q_{t}^{s}+\left(1-v_{t}\right)\left(1-q_{t}^{s}\right)} .
$$

Equation (14) can be used to prove the existence of at least one locally stable steadystate:

Proposition 3: There exists at least one locally stable stationary state $q^{s^{*}}$ where $0<q^{s^{*}}<1$.

Proof: From equation (14) we see that $\dot{q}_{t}^{s}(0)=\dot{q}_{t}^{s}(1)=0$, thus $q^{s}=1$ and $q_{t}^{s}=0$ are steady states. From equation (5) we see that $d_{t}^{i}>0 \forall 0 \leq q_{t}^{i}<1$ and $d_{t}^{i}=0$ for $q_{t}^{i}=1$. By differentiating equation (14) with respect to $q_{t}^{s}$ we arrive at:

$$
\begin{aligned}
& \left.\frac{\partial \dot{q_{t}^{s}}}{\partial q_{t}^{s}}\right|_{q_{t}^{s}=0}=\frac{v_{t}}{1-v_{t}} d_{t}^{s}>0 \\
& \left.\frac{\partial \dot{q}_{t}^{s}}{\partial q_{t}^{s}}\right|_{q_{t}^{s}=1}=\frac{1-v_{t}}{v_{t}} d_{t}^{r}>0 .
\end{aligned}
$$

From equations (15) and (16) we conclude that $q_{t}^{s}=1$ and $q_{t}^{s}=0$ are unstable steady states. Continuity of the map from $q_{t}^{s}$ to $\dot{q}_{t}^{s}$ presented by equation (14) implies the existence of at least one interior stationary solution which is locally stable ${ }^{20}$.

\footnotetext{
${ }^{19}$ We use continuous time approximation to calculate the dynamics of secularization (see also Bisin and Verdier, 2001a).

${ }^{20}$ See also Bisin and Verdier (2001a).
} 


\section{Simulations and derivation of corollaries}

To simulate equation (14) we choose functional forms in accordance with the model's assumptions. In particular, we assume that the utility derived from rearing offspring is: $f^{i}\left(n_{t}^{i}\right)=k^{i} A^{i} \sqrt{n_{t}^{i}}$; the cost of rearing offspring is: $\phi^{i}\left(n_{t}^{i}\right)=\left\{\begin{array}{l}0 \quad \text { if } n_{t}^{i}=0 \\ B^{i} n_{t}^{i} \text { if } n_{t}^{i}>0\end{array}\right.$; and the cost

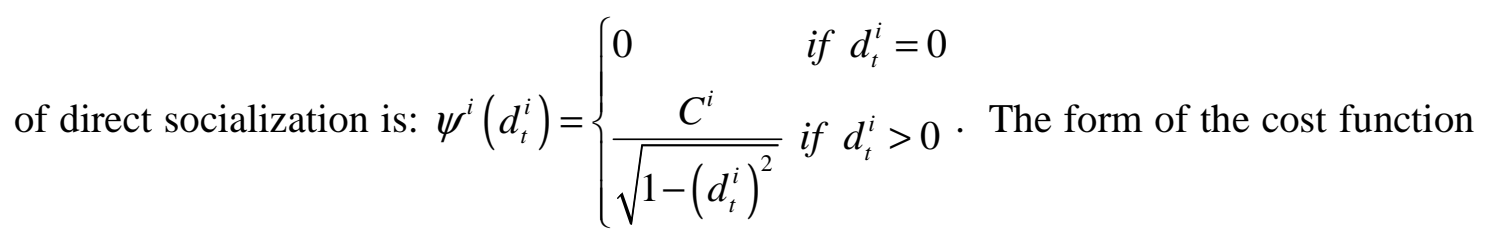
that is associated with direct socialization effort, $\psi^{i}\left(d_{t}^{i}\right)$, is borrowed from Einstein's relativity theory and it indicates that the cost of direct socialization is increasing and convex and converges to infinity as $d_{t}^{i}$ approaches unity. The utility function is therefore:

$$
u_{t}^{i}=k^{i} A^{i} \sqrt{n_{t}^{i}}+n_{t}^{i}\left(\left(d_{t}^{i}+\left(1-d_{t}^{i}\right) q_{t}^{i}\right) \Delta V^{i}+V^{i j}\right)-B^{i} n_{t}^{i}-\frac{C^{i} n_{t}^{i}}{\sqrt{1-\left(d_{t}^{i}\right)^{2}}}
$$

where: $i \in\{r, s\}$ and $k^{s}=1$ (a numeraire). The first order conditions with respect to $n_{t}^{i}$ and $d_{t}^{i}$ are:

$$
\begin{aligned}
& \frac{\partial u_{t}^{i}}{\partial n_{t}^{i}}=\frac{k^{i} A^{i}}{2 \sqrt{n_{t}^{i}}}+\left(d_{t}^{i}+q_{t}^{i}\left(1-d_{t}^{i}\right)\right) \Delta V^{i}+V^{i j}-B^{i}-\frac{C^{i}}{\sqrt{1-\left(d_{t}^{i}\right)^{2}}}=0 \\
& \frac{\partial u_{t}^{i}}{\partial d_{t}^{i}}=\left(1-q_{t}^{i}\right) \Delta V^{i}-\frac{C^{i} d_{t}^{i}}{\left(1-\left(d_{t}^{i}\right)^{2}\right)^{1.5}}=0 .
\end{aligned}
$$

In the following section we simulate equation (14) to obtain the dynamics of secularization (that is measured by the change in the share of the secular population), for different parameter values. Simulations are helpful for better understanding the secularization process that is presented in the theoretical model, and in particular, where the theory does not provide clear-cut results. 
We prefer to present a case of multiple steady-states since it demonstrates both intuitive but also less intuitive possible theoretical outcomes. The question which type of steadystate better reflects real world situations is an empirical one and will be clarified in section 5. The values of the parameters in the simulations were chosen to produce multiple steady-states and are not based on real world data. Obviously, they reflect the set of our assumptions. We start with:

1) The base case:

$$
A^{s}=A^{r}=0.9, B^{s}=B^{r}=0.9, C^{s}=4.3, C^{r}=4.5, k^{r}=1.5, \Delta V^{i}=2, V^{j}=4 \quad:^{.21}
$$

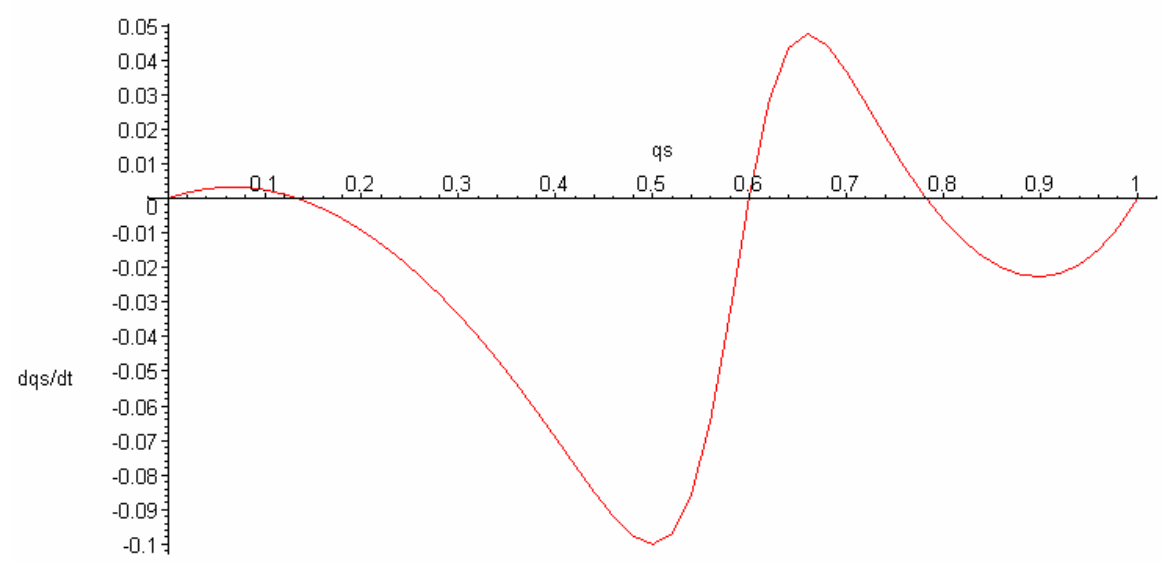

Here we have two stable equilibrium points, one at $q^{s} \approx 0.13$ and another at $q^{s} \approx 0.78$. Notice that $q^{s} \approx 0.6$ is an unstable equilibrium point, above which the share of the secular population increases over time and converges to $q^{s} \approx 0.78$, and below which the share of the secular population decreases over time and converges to $q^{s} \approx 0.13^{22}$. The first simulation leads to the first corollary:

\footnotetext{
${ }^{21}$ Note that we assume that the transmission of religious values is more costly than the transmission of secular values. For instance, religious schools are usually more expensive than regular public schools and in many countries they are private and charge high tuition fees. Another example, dietary restrictions of food consumption in the Jewish and Moslem religions are costly. See also Iannaccone (1998).

${ }^{22}$ Although the existence of a unique stable steady-state is possible, we preferred to use the multiple equilibriums case for comparative statics, since it better demonstrates all possible outcomes.
} 
Corollary 1: Secularization in period 1 has a parabolic relation with secularization in period 0 around the stable steady-state. Up to some level, an increase in secularization in period 0 increases secularization in period 1, and then, a negative relation between secularization in periods 0 and 1 is envisioned.

This simulation provides insights into the secularization process that can not be gained explicitly from the theoretical model: The theory allows for both a positive and a negative relationship between the shares of a type $i$ sub-population $(i=r, s)$ in two subsequent periods. It follows from equations (8) and (9) (and also from equations (18)-(19)) that as the share of type $i$ sub-population $(i=r, s)$ within the general population is increasing, it becomes more fertile. But on the other hand, it also invests less in direct socialization (counting more on oblique socialization $q^{i}$ ) leading to the result of the ambiguous relation stated in corollary 1 .

2) A decrease in the religious 'taste for children' $\left(k^{r}\right)$ :

Next we will verify the effect that an exogenous decrease in the religious 'taste for children' has on secularization. A decrease in the religious 'taste for children' could stem, for example, from an increase in religious women's general education that leads to a higher cost of time and to an increase in labor force participation of religious women ${ }^{23}$.

$$
A^{s}=A^{r}=0.9, B^{s}=B^{r}=0.9, C^{s}=4.3, C^{r}=4.5, k^{r}=1.1, \Delta V^{i}=2, V^{j}=4
$$

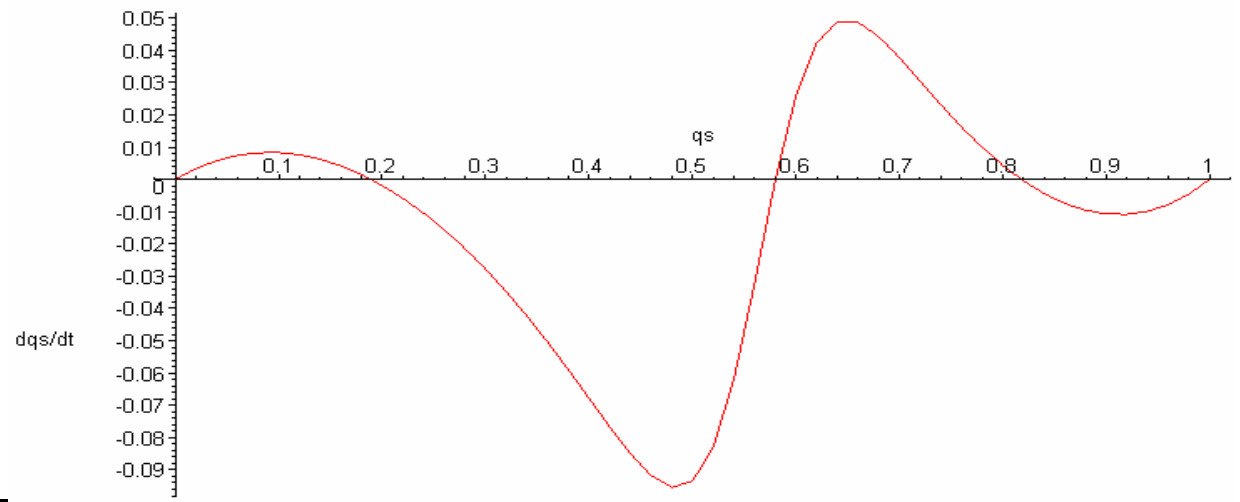

${ }^{23}$ See for example Becker (1960), Becker and Lewis (1973), Becker and I'omes (1976), Becker and Barro (1988), Hanushek (1992), and Ermisch (2003). 
As a result, the share of seculars among the general population increases in the two stable steady-states: from $q^{s} \approx 0.13$ to $q^{s} \approx 0.19$ and from $q^{s} \approx 0.78$ to $q^{s} \approx 0.82$. We can conclude with the following corollary:

Corollary 2: A decrease in the religious 'taste for children' leads to an increase in secularization.

This result also stems from the theoretical model: From equations (4) and (18) we see that a decrease in the religious taste for children results in a decline in fertility within the religious sub-population (for every $q^{s}$ ), while leaving the socialization effort per child unchanged. The decline in the fertility rate among the religious, accompanied by an unchanged socialization effort, implies an increase in secularization.

3) An increase in the religious direct socialization cost $\left(C^{r}\right)$ :

Next we will examine the effect of an increase in the religious direct socialization cost on secularization. A increase in the religious direct socialization cost can be (for instance) the result of a decline in the state's support to the religious education system, or a decrease in donations to religious institutes. In those cases the extra financial burden of socializing to religious values falls on the parents and thus increases the socialization costs. To verify the effect of cultural transmission of religious values (that is affected by the cost of transmission), we analyze the effect of an increase in the socialization cost within the religious group only $\left(C^{r}\right)$ while leaving the secular's socialization cost $\left(C^{s}\right)$ unchanged.

$$
A^{s}=A^{r}=0.9, B^{s}=B^{r}=0.9, C^{s}=4.3, C^{r}=4.6, k^{r}=1.5, \Delta V^{i}=2, V^{j}=4
$$




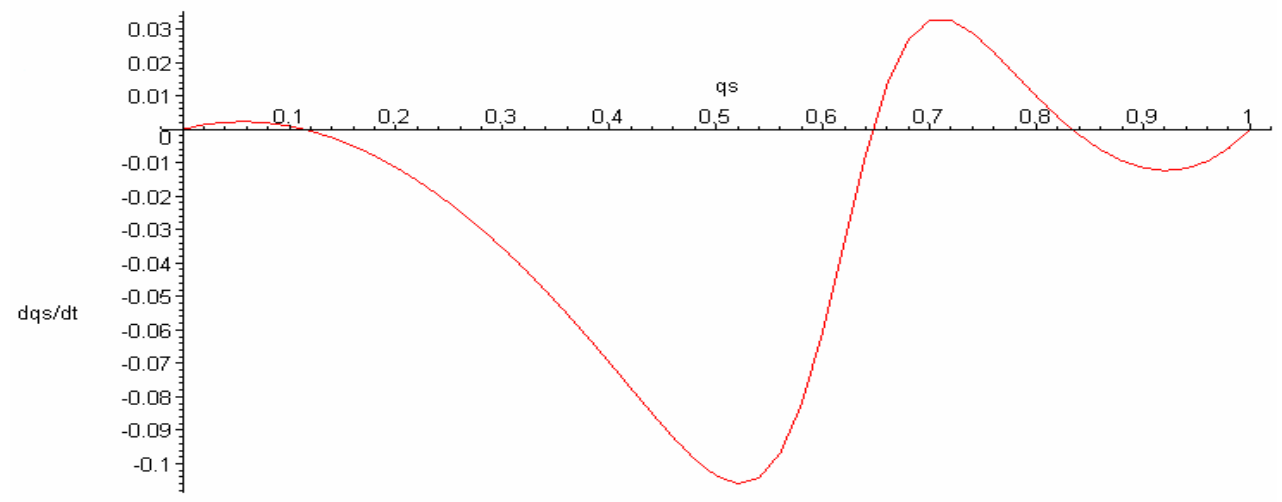

The above simulation indicates that the secular share within the general population decreased from $q^{s} \approx 0.13$ to $q^{s} \approx 0.11$ in the lower steady-state, and increased from $q^{s} \approx 0.78$ to $q^{s} \approx 0.83$ in the higher steady-state. Thus, the following corollary can be formulated:

Corollary 3: An increase in the religious direct socialization costs leads to a lower level of secularization for sufficiently small secular sub-populations, and to an increase in secularization for sufficiently large secular sub-populations.

The theoretical model leads to ambiguous results for the effect of an increase in religious socialization costs on secularization: From equations (5) and (19) we see that an increase in the religious direct socialization cost leads to a decrease in the religious direct socialization effort. However, equations (4) and (18) indicate that the effect on fertility within the religious sub-group is ambiguous: while the marginal utility from an additional offspring decreases, it is not clear what happens to the marginal cost (it could increase or decrease). The simulation reveals that fertility within the religious sub-group increases when the share of religious among the general population is large enough, and decreases for sufficiently small religious sub-populations. 
4) The next simulation looks at the interaction between the effects of an increase in the religious socialization costs $\left(C^{r}\right)$ and a decrease in the religious 'taste for children' $\left(k^{r}\right)$ : Whether the effect that an increase of the religious socialization costs has on secularization is intensified or diminished by an exogenous increase in the share of seculars, caused by a decrease in the religious taste for children:

$$
A^{s}=A^{r}=0.9, B^{s}=B^{r}=0.9, C^{s}=4.3, C^{r}=4.6, k^{r}=1.1, \Delta V^{i}=2, V^{j}=4
$$

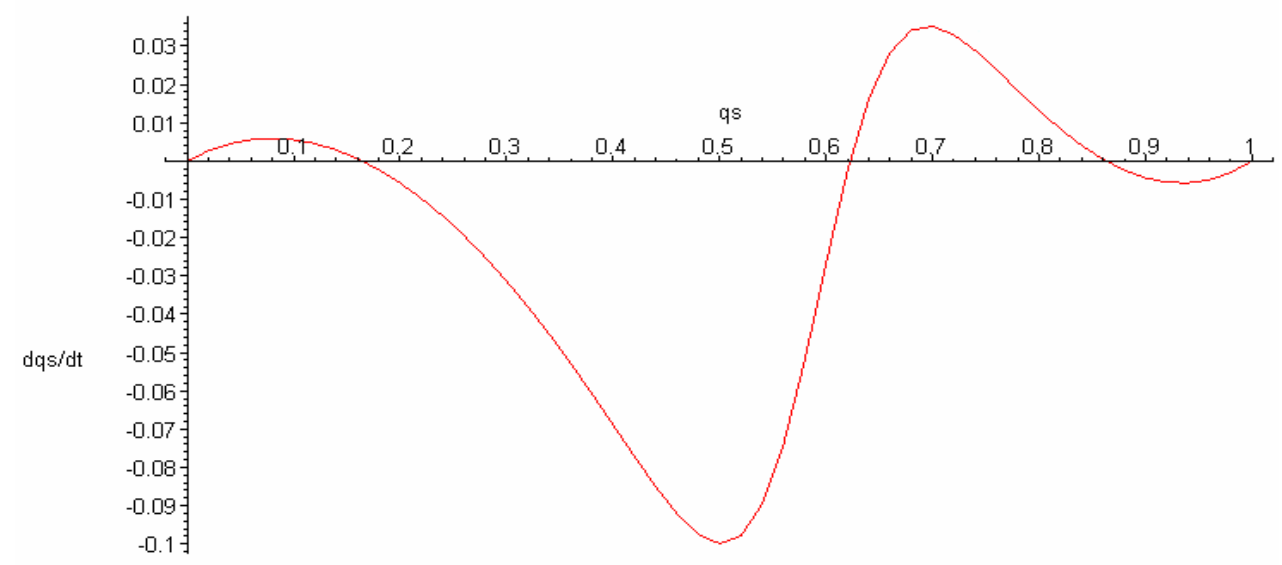

The simulation reveals that the lower steady-state increased from $q^{s} \approx 0.11$ (in the previous simulation) to $q^{s} \approx 0.16$, and the higher steady-state further increased from $q^{s} \approx 0.83$ to $q^{s} \approx 0.86$. This leads to:

Corollary 4: a decrease in the religious taste for children increases the positive effect of the increase in the religious direct socialization costs which occurs for a sufficiently large share of seculars among the general population, while diminishing the negative effect on secularization which occurs for a sufficiently small secular share within the general population.

The intuition behind this result in straightforward: An exogenous decrease in the parameter of religious 'taste for children' leads to a decrease in fertility among the 
religious population for every $q^{s}$ (see equations (4) and (18)). As a result, the increase in secularization in the higher steady-state, caused by an increase in the religious direct socialization cost, is intensified (that is, direct religious socialization effort, $d^{r}$, and oblique religious socialization, $q^{r}$, are complementary production factors in the production of next period's religiosity) while the decrease in secularization in the lower steady-state is diluted (that is, direct religious socialization effort, $d^{r}$, and oblique religious socialization, $q^{r}$, are substitute production factors in the production of next period's religiosity).

\section{The data base, variables and econometric analysis}

\subsection{Data - The ISSP (1998) description and variables' definition}

The data used for the empirical analysis were drawn from the module on National Identity of the 1998 International Social Survey Program (ISSP): Religion II. The ISSP is an ongoing effort devoted to cross-country research on national attitudes. It includes questions on attitudes, beliefs and opinions on various issues, as well as numerous questions regarding the individual's socio-economic and religious background, together with information on parents and spouses. Individuals were sampled within the following 32 countries: Australia, East Germany, West Germany, Great Britain, Northern Ireland, The United States, Austria, Hungary, Italy, Ireland, The Netherlands, Norway, Sweden, The Czech Republic, Slovenia, Poland, Bulgaria, Russia, New Zealand, Canada, The Philippines, Israel, Japan, Spain, Latvia, The Slovak Republic, France, Cyprus, Portugal, Chile, Denmark and Switzerland. Most of these countries are predominantly Christian (Catholic - $45 \%$ of the sample; Protestant $-17.3 \%$; Orthodox $-6.9 \%$ ); a small share of respondents are Jewish $(3.7 \%)$ or Moslems (1.1\%); about $7.8 \%$ were raised in other religions (e.g. Sikh, Buddhist, Hindu, Shinto, and other Christian denominations); and $18.1 \%$ identify themselves as having 'no religion'. The data cover the European and Australian continents and North America. The African continent is excluded and South America and Asia are represented by a small number of countries (Chile, Israel, Japan and the Philippines). The research is therefore pertaining to Europe and North-America, and a few other countries. The more homogeneous European sample is also analyzed 
separately. The samples were also decomposed by gender, to reveal differences between men and women.

This study relates to the evolutionary process of secularization. While there are numerous definitions for 'secularization' (see Tschannen, 1991; and Swatos and Christiano, 1999, for reviews. See also footnote 3), the principal thrust in secularization theory has been the claim that "in the face of scientific rationality, religion's influence on all aspects of life from personal habits to social institutions - is in dramatic decline" (Swatos and Christiano, 1999: 214). In this paper we look at religious personal habits and use the frequency of attendance of church services as a proxy of religiousness of the two generations, of the parents and their off-spring. For the current generation (the respondents) there is also information on their prayer habits.

The measure of secularization of the current generation $\left(q_{1}^{s}\right)$ is based on the responses to the question: "How often do you attend religious services at a church?" that has the following 6 options: never (1); once a year (2); two or three times a year times a year (3); once a month (4); two or three times a month (5); and, at least once a week (6) ${ }^{24}$. The term 'church' is used as a generic term that relates to the relevant religious place of worship (e.g., also synagogue for Jews, mosque for Moslems, etc.). A respondent was categorized as 'secular' if she/he rarely attends church services i.e., if she/he marked the original categories of (1), (2) or (3), i.e., attending religious services no more than three times a year ${ }^{25}$.

The ISSP questionnaire has also a question on private prayer habits: "How often do you pray?" The possible answers are: never (1); once a year (2); twice a year (3); few times a

\footnotetext{
${ }^{24}$ The questionnaires that were distributed in Israel and in Bulgaria included 9 categories, to reflect the somewhat different rules of congregation in Judaism and within the Christian Orthodox religion. We were able to combine categories and bring the 9 categories of the Israeli/Bulgarian questionnaires down to the 6 categories of the general questionnaires.

${ }^{25}$ As one of the referees mentioned, the same frequency of church attendance (e.g. once a month), could mean religious commitment in one country and secularization in another country. In other words, the dependent variable could be country specific. To control for country differences, we added as an explanatory/control variable the average level of church attendance in the respondent's country. The basic results did not change.
} 
year (4); about once a month (5); two or three times a month (6); almost every week (7); every week (8); several times a week (9); once a day (10); and several times a day (11). Respondents who chose one of the first three categories (rarely prays: prays no more than twice a year) were defined as 'secular. This is an alternative categorization of seculars and the two measures of 'secular' are highly correlated. The ISSP provides information on church attendance of the respondent's father and mother, as well as his own participation at church activities at the age of 12 , by asking: "When you were a child, how often did your mother/father/yourself (at age 12) attend religious services?" The options are: never (1); once a year (2); one or two times a year (3); several times a year (4); once a month (5); two or three times a month (6), almost every week (7); every week (8); several times a week (9).

These valuable retrospective data were used to define measures of 'religious' for the father/mother/child at 12. The father/mother/child was 'religious' if she/he attended services almost every week or more often (intensive church attendance: original categories of $(7)$, (8) or (9) $)^{26}$. As we do not relate to a numerical variable and combine three categories, we minimize measurement errors that result from the retrospective nature of the data. There are no retrospective questions on prayer habits.

The ISSP (1991 and 1998) appear to be the only multi-nation surveys to ask retrospective church attendance questions ${ }^{27}$. While retrospective data are frequently questioned for their reliability, there is no reason to presume that people have special difficulty recalling their religious backgrounds. Childhood attendance is a distinctive and well-defined activity, not easily confused with other activities, nor easily forgotten altogether. Individual rates of attendance tend not to vary much over time, thus limiting problems associated with the misdating of memories. People rarely confuse their childhood and adult experiences, and childhood is the only period when most people routinely observe

\footnotetext{
26 The religious rules of congregation vary between religions (e.g., many orthodox Jews congregate once or even twice a day, while Christians congregate once a week). However, the upper category is 'several times a week', and it covers the most observant respondents from all religions. It follows that the dummy variable 'intensive practice' includes intensive worshippers of all religions.

${ }^{27}$ There is a major American survey, The General Social Surveys (GSS), that included analogous questions in 1983-1986, 1988 and 1989 (Davis and Smith, 1998), but they were administrated only in the US.
} 
their parents' religious activities. Iannaccone (2003) assessed the reliability of the ISSP retrospective attendance data by comparing them to the GSS American data, the American Catholic Surveys conducted in 1963 and 1974 by NORC, and additional evidence from surveys conducted in Canada the US and Europe. He reached the conclusion that the ISSP data "stand up to numerous different tests of internal and external consistency" (page 34$)^{28}$.

\subsection{Regression analysis: Logistic 'secularization equations'}

\subsubsection{Variables and testing of corollaries}

To better understand the secularization process and gain more insight into the link between the model's parameters and the resulting trend of secularization, regression analysis was used for the estimation of the probability to be currently secular, $q_{1}^{s}$, in terms of the model. The dependent variable was a dichotomous variable that received the value of 1 for a 'secular' respondent (defined above) and 0 otherwise ${ }^{29}$. Logistic regression was used accordingly to arrive at the odd-ratios of the independent variables. A significant odds-ratio that is smaller than 1 means that an increase (decrease) in the corresponding explanatory variable led to a decrease (increase) in the probability of secularization (and accordingly in $q_{1}^{s}$ ). Similarly, a significant odds-ratio that was larger than 1 means that there was a positive relationship between the corresponding explanatory variable and the prospects of secularization: an increase (decrease) in the former resulted in an increase (decrease) also in the latter.

\footnotetext{
${ }^{28}$ He even became poetic when he summarized: "Stop making do with scattered historical statistics, and tap the comprehensive history we collectively carry in our minds. Stop grinding the same old survey questions through ever more complex calculations, and begin mining the global storehouse of retrospective data. Let others wait for decades of polls spanning dozens of countries; reconstruct the past now" (page 33).

29 The dependent variable was defined as a dummy variable that reflects the topic of this study which is secularization. We also experimented with an alternative secularization dependent variable that relates to a very low frequency of prayer. The results were similar in terms of sign and significance. Using current mass attendance is also more consistent with the use of parental and childhood mass attendance (there is no information on parental and childhood prayer habits).

Moreover, by using the richer information on mass attendance (6 levels) and prayer (11 levels) and estimating an equation of religiosity (using Ordered Logit), we also arrived at results that are in line with the model predictions. In order to save space and as our direct topic is secularization (and not degree of religiosity) we prefer to present the Logit equations of secularization (dichotomous variable) and in terms of attendance of church services.
} 
The first corollary relates to the relationship between $q_{0}^{s}$ (or $1-q_{0}^{r}$ ), which is the share of secular individuals in the respondent's neighbourhood when he was a child, and the dependent variable $\left(q_{1}^{s}\right) . q_{0}^{s}$ is not known. However, as we have a multi-country sample we can instead relate to the diversity of religions in the country of residence. In more religiously pluralistic countries, there is a lower tendency that the respondent lived among fellows of his religion, and the oblique transmission is therefore supposed to be lower. Religious diversity (pluralism) therefore represents a proxy for $q_{0}^{s}$.

The $P$ index that represents religious pluralism (diversity), was defined as $\mathrm{P}=1-\mathrm{HHI}$, where HHI is the Herfindahl-Hirschman index of concentration, defined as $\mathrm{HHI}=\sum_{i=1}^{n} s_{i}^{2}$, the sum of squares of the shares of the country's religious denominations ${ }^{30}$. It follows that $P$ ranges between 0 (if everyone belongs to the same religion) and (almost) 1 (if there are a large number of religions, each of which covers a negligible fraction of the population). The larger $\mathrm{P}$ is, the more religiously diverse the country is said to be (see also Lieberson, 1969).

The model relates to $q_{0}^{s}(\mathrm{P})$ when the respondent was a child, while we are using $\mathrm{P}$ for 1998. However, religious diversity of countries does not change significantly over time and it can be assumed that the current level of religious pluralism is very similar to the respective level a few decades ago when the respondent was a child. It follows from Corollary 1 that a non-linear parabolic relationship between $\mathrm{P}$ and secularization with a maximum point is expected. We therefore arrive at:

Hypothesis 1: Religious diversity has a non-linear parabolic effect on secularization. Up to some diversity level, secularization rises when diversity increases and then a negative relationship is expected.

\footnotetext{
${ }^{30}$ The HHI is borrowed from the analysis of industries, where $s_{i}$ is the market share of firm $i$, in a given industry. HHI serves as a measure of the competitiveness of an industry. In an industry with a single monopolistic producer, HHI will equal 1 . If the industry is composed of $n$ firms of equal size, then HHI $=$ $1 / n$, and as the number of firms is increasing HHI, is approaching 0 .
} 
As has been noted in the literature review in section 2 , the literature includes two opposing theories on the relationship between religious diversity and secularization. While sociologists who advocated demand-side views claimed that more diversity leads to higher prospects of secularization, economists who believe in supply-side theories claimed the very opposite. The theoretical model does not lead to a clear-cut conclusion; however, the simulation-based Corollary 1 expected an inverted $U$ shaped relationship between pluralism and secularization, indicating that up to some level of religious diversity demand-side forces are the more dominant, whereas after this point supply-side forces take the lead. It appears that this prediction is innovative and has not yet been suggested in the literature.

Corollary 3 relates to the effect of an increase in the cost of religious cultural transmission $\left(C^{r}\right)$ on the secularization of the children's generation (see section 4). The ISSP does not have any information on these costs. However the rich ISSP data base facilitates an indirect test of Corollary 3 .

In order to test Corollary 3 we use two assumptions: (i) religious cultural transmission is accomplished by taking children to the church on a regular basis, as well as by having a religiously homogamous household and by parental frequent attendance of church services (that signals the importance of religious norms and behavior); (ii) the standard assumption of a negative relationship between price and quantity (everything else being equal) holds, and intensified religious behavior is a result of lower costs. It follows that more intensive church attendance reflects lower costs (lower $C^{r}$ ). Another assumption is that as the share of seculars in the countries of our sample is relatively large, we are the upper steady-state.

Parental religious socialization effort $\left(d_{0}^{r}\right)$, that is negatively related to the cost of parental cultural religious transmission $\left(C^{r}\right)$ is proxied using four complimentary variables: (a) a 'religious' mother; (b) a 'religious' father; (c) a 'religious' child at the 
age of 12; and (d) a religiously homogamous family, where the two parents had the same religion.

The following retrospective variables have been defined:

- Religious (intensively practicing) mother $=1$; if the mother attended church services almost every week, every week or several times a week (categories (7); (8); or (9)).

- Religious (intensively practicing) father $=1$; if the father attended church services almost every week, every week or several times a week (same three categories).

- Religious (intensively practicing) child=1; if the respondent, when he was 12 years old, attended church services almost every week, every week or several times a week (same three categories).

- The two parents had the same religion $=1$; if the mother and the father had the same religious denomination (when the respondent was a child).

Corollary 3 predicts that a decrease in the religious direct socialization effort (caused by an increase in direct socialization costs) results in a higher secular share in the next period $\left(q_{1}^{s}\right)$. This relationship is quite obvious: children who were exposed to intensive religious practice have a higher tendency to follow religious behaviour when they grow up. Moreover, a natural assumption is that more religious parents (who cherish the religious rules and norms) invest more in the children's religious capital, using their time and financial resources. Religious transmission is more efficient if the two parents had the same religious affiliation. If the founding couple did not share the same religion, they were less likely to pass on a religious legacy due to disagreement about religious rules. Additionally, if the mother and father had different religious denominations, affiliation with the religion of one of the parents could lead to conflict with the other one, thus leading to the abandonment of religious practice altogether.

The next hypotheses therefore follow: 
Hypothesis 2: There is a negative relationship between having a mother who intensively practiced (was 'religious') during the respondent's childhood (first generation), and secularization later on in life (second generation);

Hypothesis 3: There is a negative relationship between having a father who intensively practiced (was 'religious') during the respondent's childhood (first generation), and secularization later on in life (second generation);

Hypothesis 4: There is a negative relationship between intensively practicing at the age of 12 (effort exerted by parents - first generation - who took the child to church), and secularization later on in life (second generation);

The three alternative estimates of the effect that intensity of church attendance (of the mother, the father and the child) has on secularization will enable comparing the magnitudes of the influence of the mother, the father and the child's own religious childhood experience.

Hypothesis 5: The probability of secularization is lower if both parents had the same religious affiliation.

Corollary 4 relates to the effect of interactions between $d_{0}^{r}$ and $q_{0}^{s}\left(=1-q_{0}^{r}\right)$ on secularization $\left(q_{1}^{s}\right)$. It suggests that the effect of a decrease in the religious direct socialization effort, $d_{0}^{r}$, (caused by an increase in the religious direct socialization costs $\left(C^{r}\right)$ ) for relatively large shares of seculars is intensified by an increase in the share of seculars among the general population, $q_{0}^{s}$ (caused by a decrease in the religious taste for children $\left(k^{r}\right)$ ). In other words, the interaction term $d_{0}^{r} * q_{0}^{s}$ in the secularization equation is positive. 
As suggested above, the diversity index $\mathrm{P}$ is a proxy for $q_{0}^{s}$, while a religious mother/father/child and a religiously homogamous household are proxies for $d_{0}^{r}$. The cross effects of Corollary 4 can therefore be tested by using the following interaction variables: ( $\mathrm{P} *$ religious mother); ( $\mathrm{P} *$ religious father); ( $\mathrm{P} *$ religious child at 12$)$; and (P*religiously homogamous household).

We therefore arrive at:

Hypotheses 6-9: The cross-effects of $\mathrm{P}$ and a religious mother; a religious father; a religious child at the age of 12; and a religiously homogamous parental household are all positive.

In order to arrive at net effects of our core variables on secularization, several sociodemographic characteristics have also been included as explanatory variables. These include:

- Age: Age embodies cohort effects: secularization was not common decades ago and has increased during recent years. It follows that older people belong to a cohort when secularization was less common and therefore have a lower tendency to become secular. 'Age' was represented by a set of dummy variables (60 and over; 46-59; 31-45; with 30 and below as the reference group), to allow for a non-linear effect of age.

- Education: There is ambiguity regarding the effect of education on church attendance. There are two opposing channels that relate education with churchgoing: (1) the first points to a negative relation because more educated people tend to be more rational and less spiritual. Moreover, education decreases belief in the returns of religious activity, thereby reducing the incentives to participate in these activities; (2) an opposing channel leads to a positive relationship between education and church attendance via a social networking effect: religious activity is a major form of social interaction (Durkheim, 
1995). Social group membership almost universally rises with education ${ }^{31}$ and the church is simply another form of a social group. The benefits stem from networking effects that could even lead to improvements in the worshipper's financial and professional prospects. The two conflicting effects could lead to a (combined) positive or negative correlation between education and churchgoing, or to an insignificant correlation. Education was defined by dummy variables that relate to the last school attended by the respondent (academic; high school; with elementary school as the reference group)

- Marital status variables: that included: marital status (=1 if married); number of people in household; and (married*spouse has 'no religion'). There is no consensus in the economics literature on the correlation between marital status and religious practice, or number of children and the intensity of religious practice (see Brañas-Garza and Neuman, 2004, for a more detailed discussion). Obviously, if the respondent is married to a spouse who identifies himself as having 'no religion', it increases his prospects to be secular.

- Country specific variable: per-capita GDP, (and the index of religious pluralism P, described above): This variable was included to control for differences between countries $^{32}$. Alternatively, Fixed-Effects could have been used. The two country-specific variables, namely, P and per-capita GDP were used instead. Moreover, as we are interested in the effect of religious pluralism on secularization, this version is preferable to Fixed-Effects. In order to control for intra-country correlations between observations of respondents from the same country, clustered (by country) standard errors were used. We are presenting also the Fixed-Effects version (Table 3) in order to demonstrate that the results for the core explanatory variables are similar ${ }^{33}$. In Table 3 we are also using the alternative proxy for secularization, namely very low frequencies of prayer (no more than twice a year=1). The basic results hold for this definition too.

\footnotetext{
31 Sacerdote and Glaeser (2001) report a positive connection between schooling and social group membership in almost all the 69 countries they examined.

${ }^{32}$ There is an extensive literature on the relationship between a country's growth level or development level (measured by per-capita GDP) and secularization/religiosity (for instance, Chaves, 1989; de-la Croix and Michel, 2002; McCleary and Barro, 2006; Franck and Iannaccone, 2009). Proponents of demand-side theories suggest that increased economic development leads to decreases in religiosity (increases secularization). Our model does not relate to this topic and per-capita GDP is used as a control variable. Nevertheless, the empirical results can be related to the ongoing dispute in the literature.

${ }^{33}$ Obviously, as in this version the religious pluralism variables are missing, only hypotheses $2-5$ can be tested.
} 
Estimations were performed separately for the two genders and also repeated for the more homogeneous European sub-sample.

\subsubsection{Findings}

Sample characteristics: Appendix Table B1 presents the characteristics of the samples used for the estimation of the secularization equations. The average characteristics of the European sub-sample are similar to those of the larger sample. Pooling the data for the 32 countries, we found that $44 \%$ of the women and $52 \%$ of the men were 'secular' at the time of the survey. The figures were very similar within the European countries ( $43 \%$ and $53 \%$ of women and men, respectively). The percentage of 'religious' (intensively practicing) mothers is larger than the corresponding figure for the fathers (over $40 \%$ and $30 \%$, respectively). Close to $50 \%$ of respondents were 'religious' at the age of 12 . The lower percentage of women who are currently 'secular' and the larger share of 'religious' mothers (compared to men/fathers) is in line with theories and findings of other studies showing that women are generally more religious (Sandomirsky and Wilson, 1990; Sherkat, 1991; Beit-Hallahmi, 1997; Loveland, 2003; Brañas-Garza and Neuman, 2004). The means of the other socio-economic explanatory variables are similar for the two genders. The countries are not very pluralistic in terms of existing religions within the country: An average pluralism index of 0.377 with a Standard-Deviation of $0.243(0.351$ in Europe, $\mathrm{SD}=0.238$ ) indicates quite limited diversity.

Secularization equations with country-specific variables (clustered by country standarderrors, no interacted effects): Table 1 presents results of 'Secularization Equations'. The coefficients are the odds-ratios, except for the figures that relate to the $\mathrm{P}$ and $\mathrm{P}$ squared variables that are the raw coefficients of the Logit regression ${ }^{34}$. Odds-ratios that are smaller than 1 correspond to negative raw coefficients (of the Logit regression), indicating a negative relationship between the explanatory variable under discussion and

\footnotetext{
${ }^{34}$ Following the terminology used by the Stata statistical package, we use the term 'Logit' for the estimation procedure that maximizes the logarithm of the likelihood function. The coefficient of the Logit regression describes the effect of the explanatory variable on the logit (or log-odds) of the dependent variable. Oddsratios can then be calculated by calculating e (the natural logarithm) to the power of the coefficient of the Logit regression. An alternative way to obtain odds-ratios employs the logistic' command. 'Logistic' fixes exactly the same model as 'logit', but its output table displays odds-ratios rather than coefficients (Hamilton, 2004: 269).
} 
the probability of secularization (an increase in the explanatory variable leads to a decrease in the probability of becoming secular, and vice versa). Similarly, an odds-ratio that is larger than 1 corresponds to a positive coefficient of the Logit regression, and means that the probability of secularization is positively related to the relevant explanatory variable.

As is evident from Table 1, diversity of religions in the country of residence $(\mathrm{P})$ has a parabolic significant effect on secularization, with a maximum point: The likelihood of secularization first rises with the increase in religions pluralism and after it reaches a maximum, the trend changes to a decrease in secularization. The peak is around a pluralism level of 0.5. It is above the average level that is 0.377 within the larger sample and 0.351 in the European countries. Hypothesis 1 (based on Corollary 1) is therefore supported by our data.

Table 1: Logistic Regressions of Secularization (standard-errors clustered by country), ISSP 1998.

Dependent variable: Respondent Attends religious services no more than three times a year.

\begin{tabular}{|c|c|c|c|c|}
\hline \multirow[t]{2}{*}{ Explanatory variables } & \multicolumn{2}{|c|}{ WHOLE SAMPLE } & \multicolumn{2}{|c|}{ EUROPE } \\
\hline & Female & Male & Female & Male \\
\hline $\begin{array}{l}\text { Exposure to religiosity during childhood } \\
\text { Religious mother (attended church services } \\
\text { intensively) }\end{array}$ & $\begin{array}{c}0.572 \\
(0.000)\end{array}$ & $\begin{array}{c}0.610 \\
(0.000)\end{array}$ & $\begin{array}{c}0.627 \\
(0.000)\end{array}$ & $\begin{array}{c}0.698 \\
(0.000)\end{array}$ \\
\hline Religious father (attended church services intensively) & $\begin{array}{c}0.681 \\
(0.005)\end{array}$ & $\begin{array}{c}0.563 \\
(0.000)\end{array}$ & $\begin{array}{c}0.581 \\
(0.000)\end{array}$ & $\begin{array}{c}0.490 \\
(0.000)\end{array}$ \\
\hline $\begin{array}{r}\text { Religious respondent at } 12 \text { (attended church services } \\
\text { intensively) }\end{array}$ & $\begin{array}{c}0.550 \\
(0.000)\end{array}$ & $\begin{array}{c}0.672 \\
(0.001)\end{array}$ & $\begin{array}{c}0.573 \\
(0.000)\end{array}$ & $\begin{array}{c}0.605 \\
(0.000)\end{array}$ \\
\hline $\begin{array}{l}\text { Religiously homogamous parents } \\
\text { (Mother and father had the same religion) }\end{array}$ & $\begin{array}{l}0.675 \\
(0.000)\end{array}$ & $\begin{array}{c}0.630 \\
(0.001)\end{array}$ & $\begin{array}{l}0.596 \\
(0.000) \\
\end{array}$ & $\begin{array}{c}0.577 \\
(0.000) \\
\end{array}$ \\
\hline Marital variables & & & & \\
\hline Married & $\begin{array}{c}0.753 \\
(0.000)\end{array}$ & $\begin{array}{c}0.656 \\
(0.000)\end{array}$ & $\begin{array}{c}0.731 \\
(0.001)\end{array}$ & $\begin{array}{c}0.623 \\
(0.000)\end{array}$ \\
\hline Married and spouse has 'no religion' & $\begin{array}{l}3.371 \\
(0.000)\end{array}$ & $\begin{array}{r}5.249 \\
(0.000)\end{array}$ & $\begin{array}{l}4.039 \\
(0.000)\end{array}$ & $\begin{array}{r}7.779 \\
(0.000)\end{array}$ \\
\hline Number of people in household & $\begin{array}{c}0.904 \\
(0.005)\end{array}$ & $\begin{array}{c}0.898 \\
(0.000)\end{array}$ & $\begin{array}{c}0.917 \\
(0.001) \\
\end{array}$ & $\begin{array}{c}0.934 \\
(0.002) \\
\end{array}$ \\
\hline 60 and over & $\begin{array}{c}0.447 \\
(0.000)\end{array}$ & $\begin{array}{c}0.730 \\
(0.051)\end{array}$ & $\begin{array}{c}0.475 \\
(0.000)\end{array}$ & $\begin{array}{c}0.832 \\
(0.316)\end{array}$ \\
\hline
\end{tabular}




\begin{tabular}{|c|c|c|c|c|}
\hline \multirow[t]{2}{*}{ Explanatory variables } & \multicolumn{2}{|c|}{ WHOLE SAMPLE } & \multicolumn{2}{|c|}{ EUROPE } \\
\hline & Female & Male & Female & Male \\
\hline $46-$ to-59 & $\begin{array}{c}0.676 \\
(0.000)\end{array}$ & $\begin{array}{c}1.014 \\
(0.891)\end{array}$ & $\begin{array}{c}0.673 \\
(0.000)\end{array}$ & $\begin{array}{c}1.145 \\
(0.238)\end{array}$ \\
\hline $31-$ to- 45 & $\begin{array}{c}0.822 \\
(0.003)\end{array}$ & $\begin{array}{c}0.997 \\
(0.975)\end{array}$ & $\begin{array}{c}0.833 \\
(0.023)\end{array}$ & $\begin{array}{l}1.102 \\
(0.344)\end{array}$ \\
\hline 30 and under & ref. & ref. & ref. & ref. \\
\hline Education (last school attended) & & & & \\
\hline Academic & $\begin{array}{c}1.131 \\
(0.207)\end{array}$ & $\begin{array}{c}0.985 \\
(0.875)\end{array}$ & $\begin{array}{c}1.072 \\
(0.486)\end{array}$ & $\begin{array}{c}0.984 \\
(0.873)\end{array}$ \\
\hline High school & $\begin{array}{c}1.216 \\
(0.046)\end{array}$ & $\begin{array}{c}1.086 \\
(0.408)\end{array}$ & $\begin{array}{r}1.172 \\
(0.123)\end{array}$ & $\begin{array}{c}1.061 \\
(0.558)\end{array}$ \\
\hline Elementary school & ref. & ref. & ref. & ref. \\
\hline Country - specific characteristics & & & & \\
\hline Per-capita GDP (divided by 1000) & $\begin{array}{c}1.021 \\
(0.059)\end{array}$ & $\begin{array}{c}1.009 \\
(0.464)\end{array}$ & $\begin{array}{c}1.031 \\
(0.001)\end{array}$ & $\begin{array}{c}1.021 \\
(0.042)\end{array}$ \\
\hline Religious Pluralism Index $(\mathrm{P})$ & $\begin{array}{l}2.658 \\
(0.133)\end{array}$ & $\begin{array}{c}3.985 \\
(0.027)\end{array}$ & $\begin{array}{l}3.900 \\
(0.039)\end{array}$ & $\begin{array}{c}5.733 \\
(0.002)\end{array}$ \\
\hline Religious Pluralism Index squared $\left(\mathrm{P}^{* * 2}\right)$ & $\begin{array}{l}-2.577 \\
(0.219)\end{array}$ & $\begin{array}{l}-3.880 \\
(0.053)\end{array}$ & $\begin{array}{l}-4.172 \\
(0.065)\end{array}$ & $\begin{array}{l}-6.227 \\
(0.004)\end{array}$ \\
\hline Sample size & 14,955 & 12,372 & 12,382 & 9,936 \\
\hline Pseudo $\mathrm{R}^{2}$ & 0.166 & 0.161 & 0.184 & 0.189 \\
\hline
\end{tabular}

Notes: 1. Stata 10 was used for estimation of Logistic regressions, with clustered (by country) standard errors, to account for repeated observations from each country.

2. p-values (significance levels) in parentheses.

3. The table presents odds-ratios for all explanatory variables, except for the Pluralism-Index where the figures relate to the raw coefficients of the Logit regression

As expected, exposure to religious practice during childhood significantly reduces the likelihood of becoming secular later on in life (odds-ratios smaller than one). The effects of the various aspects of exposure (maternal/paternal/own intensive religious practice) are not dramatically different. They are also not very different for the two genders or between the larger sample and the European sub-sample. A religiously homogamous family also has a significant negative effect on secularization. These findings support Hypotheses 2-5 (based on Corollary 3).

It should be noted that the significant correlation between parental/childhood church attendance and current church attendance maybe due to the existence of 'unobservable heterogeneity' at the family level, that results in spurious correlation rather than reflecting a causal effect. It, in turn, means that parental/childhood church attendance variables are 
endogenous variables in the equation that intends to explain the secularization of their children. Unfortunately, the ISSP does not include data for an instrument that will eliminate this potential statistical problem. However, we believe that the 'religiously homogamous' variable can be the kind of 'left out' variable that could give rise to the endogeneity. When this variable is included, the endogeneity problem may be eliminated. Another probable solution could be the use of an alternative dependent variable for secularization, namely 'rare prayer habits' (see Table 3). While parental and respondents' church attendance maybe driven by the same family culture (e.g., belief in the importance of networking and social ties), it is less likely that parental church attendance and children's private/intimate prayer are also motivated by the same forces.

The socio-demographic variables served as control variables and were not part of the theoretical model. The regression results show that: A spouse who declared that he has 'no religion' is positively correlated with the probability of secularization. Being married and having more children diminishes the probability of secularization ${ }^{35}$. The effect of age is different between the genders. Women have a constant decreasing probability to be secular as they age (over the age of 30 , which is the reference category). Age is not affecting men in the European sample and only men who are above the age of 60 have a lower probability in the larger sample. Education does not seem to affect the tendency to become secular. Given the results for per-capita GDP, secularization is more common in more developed countries. This finding lends some support to proponents of demand-side theories.

Interacted effects of country religious pluralism and exposure to religiosity during childhood: In order to examine cross-relationships between the effects of $d_{0}^{r}$ and $1-q_{0}^{r}\left(=q_{0}^{s}\right)$ (on secularization in the next generation, $\left(q_{1}^{s}\right)$ ), we study the interacted effects of their respective proxies.

Insignificant interaction terms indicate that the effects of the two factors are independent. A negative interaction effect on secularization means that religiosity of the

\footnotetext{
${ }^{35}$ Obviously, causality could run the opposite way too: respondents who were secular had a lower tendency to marry, a larger tendency to marry spouses with 'no religion', and had less children. Removing these variables from the regressions resulted in very similar regression coefficients.
} 
mother/father/child/couple (i.e., exposure to religious experiences during childhood), is more effective in producing 'religiosity' and 'against' secularization in countries that are religiously pluralistic (i.e., the effects of $d_{0}^{r}$ and $q_{0}^{r}$ are substitutes in the production of 'religiosity). Alternatively, a positive interaction term of the Logit secularization equation shows that the negative effect of a religious mother/father/child/couple is less effective and partially crowded out in countries that have more religious diversity (i.e., $d_{0}^{r}$ and $q_{0}^{r}$ are complements in the production of 'religiosity' and their effects reinforce and complement each other). Hypotheses 6-9, based on Corollary 4, suggest complementarity between the effects (for relatively large shares of seculars) leading to positive interaction effects.

While in OLS regressions, interacted effects of 2 (or more) variables (on the dependent variable) are estimated and tested by using interactions (multiplications) of the 2 variables, it appears that this is not the case when Logit regressions are used. As Norton et al. (2004) showed, in Logit regressions the interacted effect is not the coefficient of the interaction term and its statistical significance cannot be tested with a simple t-test on the coefficient of the interaction term. Moreover, Ai and Norton (2003) claim that even the sign of the coefficient of the interaction term does not necessarily show the sign of the interacted effect.

Norton et al. (2004) created the Stata command 'inteff' to calculate the 'correct' interacted effects. Tables $2 \mathrm{a}$ and $2 \mathrm{~b}$ present the results for the larger and the European samples and for the 2 genders. Only one interaction term can be used, leading to 4 repeated regressions for each case (denoted by Model 1-to-Model 4). All other explanatory variables that were included in Table 1 have been included in these regressions too (age dummies; education dummies; married; number of people in household; and country percapita GDP).

The 'inteff' command also provides graphs that portray z-statistics of the interaction effect against predicted probabilities of having low practice. Figure 1 presents the z-statistics of the interacted effect of a religious father (attended church services intensively) and the $\mathrm{P}$ index, within the female European sample. To save space we do not present all other graphs and they can be provided by the authors upon request. 
As is evident from Tables $2 \mathrm{a}$ and $2 \mathrm{~b}$, the cross-effects of the country's religious diversity (P) and exposure to religious practice during childhood are insignificant in some cases, indicating independence between the two types of effects (that proxy oblique and direct religious socialization, respectively). Complementarity between the two factors in the transmission of religious values and practice (a significant positive cross-effect indicating that more religious pluralism leads to a decrease in the negative effect of exposure to religiosity at childhood, on secularization) is found in the following cases: For womenbetween religious pluralism and father's religiosity (in the European sample), between pluralism and intensive church attendance at 12 (both in the larger sample and in the European sample) and between pluralism and a religiously homogamous household (in the European sample). For men-between religious pluralism and a religious homogamous household in both samples.

Hypotheses 6-9 are therefore partly supported. Our data does not indicate a significant positive interacted effect between a religious mother and $\mathrm{P}$ (Hypothesis 6), but we do find significant positive interacted effects of $\mathrm{P}$ and other dimensions of exposure to religiosity during childhood (Hypotheses 7-9).

Table 2a: Logistic Regressions of Secularization (standard-errors clustered by country), Whole sample, ISSP 1998.

Including interacted effects of Country Religious Pluralism with Exposure to religiosity during childhood.

\begin{tabular}{|c|c|c|c|c|}
\hline FEMALE & Model 1 & Model 2 & Model 3 & Model 4 \\
\hline Religious mother & $\begin{array}{c}0.408 \\
(0.000)\end{array}$ & $\begin{array}{c}0.555 \\
(0.000)\end{array}$ & $\begin{array}{c}0.557 \\
(0.000)\end{array}$ & $\begin{array}{c}0.557 \\
(0.000)\end{array}$ \\
\hline Religious father & $\begin{array}{l}0.685 \\
(0.010)\end{array}$ & $\begin{array}{l}0.537 \\
(0.013)\end{array}$ & $\begin{array}{l}0.680 \\
(0.008)\end{array}$ & $\begin{array}{c}0.684 \\
(0.000)\end{array}$ \\
\hline Religious respondent at 12 & $\begin{array}{l}0.526 \\
(0.000)\end{array}$ & $\begin{array}{c}0.525 \\
(0.000)\end{array}$ & $\begin{array}{l}0.338 \\
(0.000)\end{array}$ & $\begin{array}{c}0.531 \\
(0.000)\end{array}$ \\
\hline Religiously homogamous parents & $\begin{array}{c}0.670 \\
(0.000)\end{array}$ & $\begin{array}{l}0.668 \\
(0.000)\end{array}$ & $\begin{array}{c}0.672 \\
(0.000)\end{array}$ & $\begin{array}{c}0.496 \\
(0.028)\end{array}$ \\
\hline Religious Pluralism Index $(\mathrm{P})$ & $\begin{array}{l}1.218 \\
(0.648) \\
\end{array}$ & $\begin{array}{l}1.396 \\
(0.415)\end{array}$ & $\begin{array}{l}0.953 \\
(0.915) \\
\end{array}$ & $\begin{array}{l}0.999 \\
(0.998) \\
\end{array}$ \\
\hline $\mathrm{P} *$ Religious mother & $\begin{array}{c}\text { not } \\
\text { significant }\end{array}$ & - & - & - \\
\hline $\mathrm{P} *$ Religious father & - & $\begin{array}{c}\text { not } \\
\text { significant }\end{array}$ & - & - \\
\hline $\mathrm{P} *$ Religious respondent at 12 & - & - & $\begin{array}{l}\text { positive } \\
\text { effect }\end{array}$ & - \\
\hline $\begin{array}{l}\mathrm{P}^{*} \text { Religiously homogamous } \\
\text { parents }\end{array}$ & - & - & & $\begin{array}{c}\text { not } \\
\text { significant }\end{array}$ \\
\hline
\end{tabular}




\begin{tabular}{|c|c|c|c|c|}
\hline Control variables & yes & yes & yes & yes \\
\hline Sample size & 14,955 & 14,955 & 14,955 & 14,955 \\
\hline Pseudo $\mathrm{R}^{2}$ & 0.165 & 0.164 & 0.166 & 0.164 \\
\hline MALE & Model 1 & Model 2 & Model 3 & Model 4 \\
\hline Religious mother & $\begin{array}{c}0.452 \\
(0.011)\end{array}$ & $\begin{array}{c}0.576 \\
(0.000)\end{array}$ & $\begin{array}{c}0.578 \\
(0.000)\end{array}$ & $\begin{array}{c}0.579 \\
(0.000)\end{array}$ \\
\hline Religious father & $\begin{array}{c}0.557 \\
(0.000)\end{array}$ & $\begin{array}{c}0.436 \\
(0.004)\end{array}$ & $\begin{array}{c}0.558 \\
(0.000)\end{array}$ & $\begin{array}{c}0.559 \\
(0.000)\end{array}$ \\
\hline Religious respondent at 12 & $\begin{array}{c}0.649 \\
(0.000)\end{array}$ & $\begin{array}{c}0.648 \\
(0.000)\end{array}$ & $\begin{array}{c}0.512 \\
(0.065)\end{array}$ & $\begin{array}{c}0.655 \\
(0.000)\end{array}$ \\
\hline Religiously homogamous parents & $\begin{array}{c}0.632 \\
(0.001)\end{array}$ & $\begin{array}{c}0.630 \\
(0.001)\end{array}$ & $\begin{array}{c}0.635 \\
(0.001)\end{array}$ & $\begin{array}{c}0.327 \\
(0.003)\end{array}$ \\
\hline Religious Pluralism Index $(\mathrm{P})$ & $\begin{array}{l}1.681 \\
(0.418)\end{array}$ & $\begin{array}{l}1.396 \\
(0.415)\end{array}$ & $\begin{array}{c}1.683 \\
(0.463) \\
\end{array}$ & $\begin{array}{l}0.693 \\
(0.556) \\
\end{array}$ \\
\hline P*Religious mother & $\begin{array}{c}\text { not } \\
\text { significant }\end{array}$ & - & - & - \\
\hline $\mathrm{P} *$ Religious father & - & $\begin{array}{c}\text { not } \\
\text { significant }\end{array}$ & - & - \\
\hline $\mathrm{P} *$ Religious respondent at 12 & - & - & $\begin{array}{c}\text { not } \\
\text { significant }\end{array}$ & - \\
\hline $\begin{array}{l}\mathrm{P}^{*} \text { Religiously homogamous } \\
\text { parents }\end{array}$ & - & - & - & $\begin{array}{l}\text { positive } \\
\text { effect }\end{array}$ \\
\hline Control variables & yes & yes & yes & yes \\
\hline Sample size & 12,372 & 12,372 & 12,372 & 12,372 \\
\hline Pseudo $\mathrm{R}^{2}$ & 0.156 & 0.156 & 0.156 & 0.157 \\
\hline
\end{tabular}

Table 2b: Logistic Regressions of Secularization (standard-errors clustered by country), European sample, ISSP 1998.

Including interacted effects of Country Religious Pluralism with Exposure to religiosity during childhood.

\begin{tabular}{|c|c|c|c|c|}
\hline FEMALE & Model 1 & Model 2 & Model 3 & Model 4 \\
\hline Religious mother & $\begin{array}{c}0.447 \\
(0.000)\end{array}$ & $\begin{array}{c}0.605 \\
(0.000)\end{array}$ & $\begin{array}{c}0.607 \\
(0.000)\end{array}$ & $\begin{array}{c}0.608 \\
(0.000)\end{array}$ \\
\hline Religious father & $\begin{array}{c}0.562 \\
(0.000)\end{array}$ & $\begin{array}{c}0.446 \\
(0.001)\end{array}$ & $\begin{array}{c}0.560 \\
(0.000)\end{array}$ & $\begin{array}{c}0.565 \\
(0.000)\end{array}$ \\
\hline Religious respondent at 12 & $\begin{array}{c}0.549 \\
(0.000)\end{array}$ & $\begin{array}{c}0.548 \\
(0.000)\end{array}$ & $\begin{array}{c}0.366 \\
(0.000)\end{array}$ & $\begin{array}{c}0.555 \\
(0.000)\end{array}$ \\
\hline Religiously homogamous parents & $\begin{array}{c}0.582 \\
(0.000)\end{array}$ & $\begin{array}{c}0.582 \\
(0.000)\end{array}$ & $\begin{array}{c}0.584 \\
(0.000)\end{array}$ & $\begin{array}{c}0.365 \\
(0.000)\end{array}$ \\
\hline Religions Pluralism Index $(\mathrm{P})$ & $\begin{array}{c}1.318 \\
(0.498)\end{array}$ & $\begin{array}{l}1.534 \\
(0.294)\end{array}$ & $\begin{array}{l}1.075 \\
(0.853)\end{array}$ & $\begin{array}{c}0.762 \\
(0.694)\end{array}$ \\
\hline P*Religious mother & $\begin{array}{c}\text { not } \\
\text { significant }\end{array}$ & - & - & - \\
\hline $\mathrm{P}^{*}$ Religious father & - & $\begin{array}{l}\text { positive } \\
\text { effect }\end{array}$ & - & - \\
\hline $\mathrm{P} *$ Religious respondent at 12 & - & & $\begin{array}{l}\text { positive } \\
\text { effect }\end{array}$ & - \\
\hline $\mathrm{P}^{*}$ Religiously homogamous & - & - & - & positive \\
\hline
\end{tabular}




\begin{tabular}{|c|c|c|c|c|}
\hline parents & & & & effect \\
\hline Control variables & yes & yes & yes & yes \\
\hline Sample size & 12,382 & 12,382 & 12,382 & 12,382 \\
\hline Pseudo $\mathrm{R}^{2}$ & 0.181 & 0.180 & 0.182 & 0.180 \\
\hline MALE & Model 1 & Model 2 & Model 3 & Model 4 \\
\hline Religious mother & $\begin{array}{c}0.545 \\
(0.046)\end{array}$ & $\begin{array}{c}0.659 \\
(0.000)\end{array}$ & $\begin{array}{c}0.665 \\
(0.000)\end{array}$ & $\begin{array}{c}0.662 \\
(0.000)\end{array}$ \\
\hline Religious father & $\begin{array}{c}0.454 \\
(0.000)\end{array}$ & $\begin{array}{l}0.378 \\
(0.001)\end{array}$ & $\begin{array}{l}0.456 \\
(0.000)\end{array}$ & $\begin{array}{c}0.460 \\
(0.000)\end{array}$ \\
\hline Religious respondent at 12 & $\begin{array}{l}0.597 \\
(0.000)\end{array}$ & $\begin{array}{l}0.596 \\
(0.000)\end{array}$ & $\begin{array}{l}0.514 \\
(0.097)\end{array}$ & $\begin{array}{c}0.598 \\
(0.000)\end{array}$ \\
\hline Religiously homogamous parents & $\begin{array}{r}0.569 \\
(0.001)\end{array}$ & $\begin{array}{c}0.569 \\
(0.001)\end{array}$ & $\begin{array}{c}0.572^{2} \\
(0.001)\end{array}$ & $\begin{array}{c}0.255 \\
(0.001)\end{array}$ \\
\hline Religions Pluralism Index (P) & $\begin{array}{l}2.111 \\
(0.298)\end{array}$ & $\begin{array}{l}1.534 \\
(0.294)\end{array}$ & $\begin{array}{l}2.250 \\
(0.357)\end{array}$ & $\begin{array}{c}0.539 \\
(0.344)\end{array}$ \\
\hline P*Religious mother & $\begin{array}{c}\text { not } \\
\text { significant }\end{array}$ & - & - & - \\
\hline P*Religious father & - & $\begin{array}{l}\text { not } \\
\text { significant }\end{array}$ & - & - \\
\hline P*Religious respondent at 12 & - & - & $\begin{array}{l}\text { not } \\
\text { significant }\end{array}$ & - \\
\hline $\begin{array}{l}\text { P* Religiously homogamous } \\
\text { parents }\end{array}$ & - & & 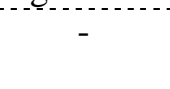 & $\begin{array}{l}\text { positive } \\
\text { effect }\end{array}$ \\
\hline Control variables & Yes & Yes & Yes & Yes \\
\hline Sample size & 9,936 & 9,936 & 9,936 & 9,936 \\
\hline Pseudo $\mathrm{R}^{2}$ & 0.179 & 0.179 & 0.179 & 0.181 \\
\hline
\end{tabular}

Notes: 1 . Stata 10 (and the 'inteff' command) were used for estimation

2. p-values (significance levels) in parentheses.

3. The table presents odds-ratios for all explanatory variables.

4. All other explanatory variables that were included in the regression reported in Table 1 were included in this regression too (age dummies; education dummies; married; number of people in household; and country per-capita GDP). 
Figure 1: z-statistics of interaction effects of country religious pluralism and religious father - female European sample.

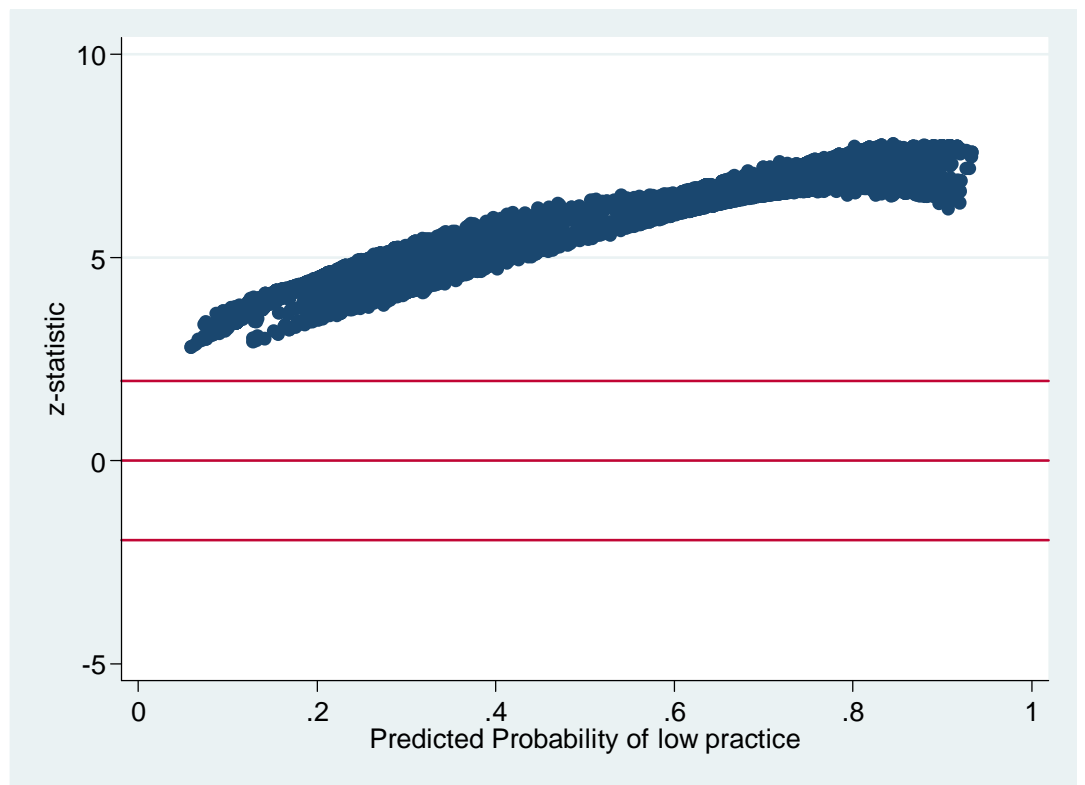

As is evident from Figure 1, the interacted effect of religious pluralism and a religious father (within the female European sample) is significant and positive.

To gain further insight, Figure 2 presents predicted probabilities of having low practice against the religious pluralism index, distinguishing between respondents with a religious and non-religious father (using the 'viblicc' command suggested by Mitchell and Chen, 2005). Figure 2 clearly portrays that the probability of being secular is lower for those who grew up with a religious father (supporting Hypothesis 3). Moreover, the probability of secularization increases with the $\mathrm{P}$ religious pluralism index only when the respondent had a religious father, indicating a positive interacted effect (on secularization) of $\mathrm{P}$ and a religious father (supporting Hypothesis 7). 
Figure 2: A graphical illustration of the interacted effect of country religious pluralism and a religious father - female European sample.

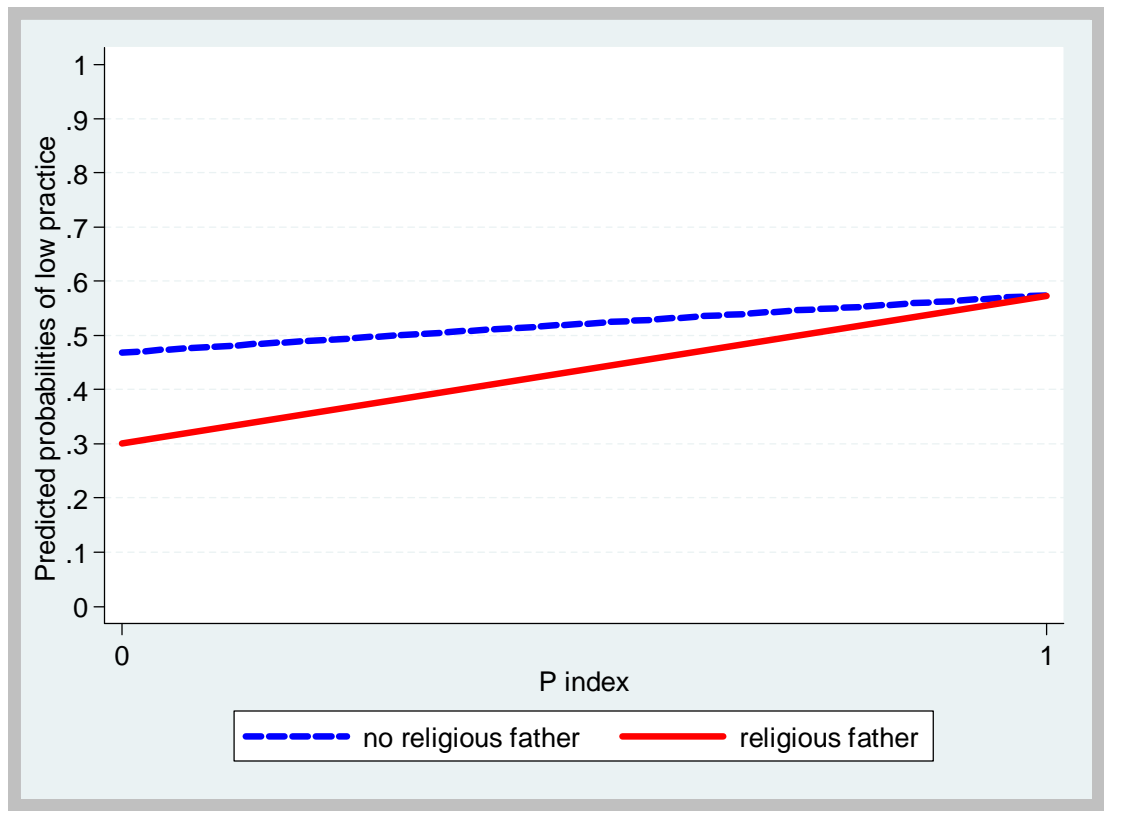

As a whole, these results indicate that in more religiously diverse countries exposure to religious practice during childhood is less effective in advancing secularization of the children's generation. In other words, religious homogeneity (proxing $q_{0}^{r}$ ) and exposure to religiosity (proxing $d_{0}^{r}$ ) are complements in 'producing' religiosity (i.e. in fighting secularization). These results are supportive of the hypotheses derived from our theoretical model ${ }^{36}$.

Fixed-Effects secularization regressions: Table 3 presents country Fixed-Effects regressions for 2 alternative dependent variables of secularization: (i) the variable used in Tables 1 and 2, namely low frequency of mass attendance (no more than few times a year); and (ii) low frequency of prayer: no more than few times a year. Church attendance and prayer are 2 dimensions of religiosity. The first relates to a public religious activity, while the second is a private/intimate religious activity. It is expected that hypotheses 2-5 will hold for the 2 dimensions of secularization. The Fixed-Effects regression, that

\footnotetext{
${ }^{36}$ Hypotheses 7, 8 and 9 are supported. Hypothesis 6 is not supported but not rejected either - the cross effects are insignificant in all sub-samples.
} 
includes country dummies/effects, does not allow for country-specific explanatory variables and therefore hypotheses 1 and 6-9 can not be tested. Nevertheless, confirmation of hypotheses 2-5 within a Fixed-Effects regression model and with the use of the 2 secularization definitions will add robustness to our results.

Table 3: Country Fixed-Effects Logistic Secularization Regressions (odds-ratios), Whole Sample, ISSP 1998.

\begin{tabular}{|c|c|c|c|c|}
\hline \multirow[t]{2}{*}{ Explanatory variables } & \multicolumn{2}{|c|}{ Rare Mass-Attendance } & \multicolumn{2}{|c|}{ Rare Prayer } \\
\hline & Female & Male & Female & Male \\
\hline \multicolumn{5}{|l|}{ Religious exposure during childhood } \\
\hline $\begin{array}{r}\text { Religious mother (attended church services } \\
\text { intensively) }\end{array}$ & $\begin{array}{c}0.652 \\
(0.000)\end{array}$ & $\begin{array}{c}0.681 \\
(0.000)\end{array}$ & $\begin{array}{c}0.652 \\
(0.000)\end{array}$ & $\begin{array}{l}0.736 \\
(0.000)\end{array}$ \\
\hline $\begin{array}{r}\text { Religious father (attended church services } \\
\text { intensively) }\end{array}$ & $\begin{array}{l}0.625 \\
(0.000)\end{array}$ & $\begin{array}{c}0.576 \\
(0.000)\end{array}$ & $\begin{array}{c}0.665 \\
(0.000)\end{array}$ & $\begin{array}{c}0.581 \\
(0.000)\end{array}$ \\
\hline $\begin{array}{l}\text { Religious respondent at } 12 \text { (attended church } \\
\text { services intensively) }\end{array}$ & $\begin{array}{c}0.572 \\
(0.000)\end{array}$ & $\begin{array}{c}0.583 \\
(0.000)\end{array}$ & $\begin{array}{c}0.412 \\
(0.000)\end{array}$ & $\begin{array}{c}0.445 \\
(0.000)\end{array}$ \\
\hline $\begin{array}{r}\text { Religiously homogamous parents } \\
\text { (Mother and father had the same religion) }\end{array}$ & $\begin{array}{c}0.677 \\
(0.000)\end{array}$ & $\begin{array}{c}0.678 \\
(0.000) \\
\end{array}$ & $\begin{array}{c}0.572 \\
(0.000) \\
\end{array}$ & $\begin{array}{r}0.604 \\
(0.000) \\
\end{array}$ \\
\hline \multicolumn{5}{|l|}{ Marital variables } \\
\hline Married & $\begin{array}{c}0.732 \\
(0.000)\end{array}$ & $\begin{array}{c}0.615 \\
(0.000)\end{array}$ & $\begin{array}{c}0.787 \\
(0.001)\end{array}$ & $\begin{array}{c}0.765 \\
(0.000)\end{array}$ \\
\hline Married and spouse has 'no religion' & $\begin{array}{l}3.669 \\
(0.000)\end{array}$ & $\begin{array}{l}6.161 \\
(0.000)\end{array}$ & $\begin{array}{l}3.656 \\
(0.000)\end{array}$ & $\begin{array}{l}4.929 \\
(0.000)\end{array}$ \\
\hline Number of people in household & $\begin{array}{c}0.912 \\
(0.000) \\
\end{array}$ & $\begin{array}{c}0.912 \\
(0.000)\end{array}$ & $\begin{array}{c}0.906 \\
(0.001)\end{array}$ & $\begin{array}{c}0.930 \\
(0.002) \\
\end{array}$ \\
\hline Age (years) & $\begin{array}{c}0.442 \\
(0.000)\end{array}$ & $\begin{array}{c}0.730 \\
(0.000)\end{array}$ & $\begin{array}{c}0.352 \\
(0.000)\end{array}$ & $\begin{array}{c}0.534 \\
(0.316)\end{array}$ \\
\hline $46-$ to-59 & $\begin{array}{c}0.676 \\
(0.000)\end{array}$ & $\begin{array}{r}1.065 \\
(0.373)\end{array}$ & $\begin{array}{c}0.583 \\
(0.000)\end{array}$ & $\begin{array}{r}0.825 \\
(0.006)\end{array}$ \\
\hline $31-$ to- 45 & $\begin{array}{r}0.834 \\
(0.001)\end{array}$ & $\begin{array}{r}1.001 \\
(0.985)\end{array}$ & $\begin{array}{r}0.859 \\
(0.007)\end{array}$ & $\begin{array}{r}0.866 \\
(0.020)\end{array}$ \\
\hline 30 and under & ref. & ref. & ref. & ref. \\
\hline \multicolumn{5}{|l|}{ Education (last school attended) } \\
\hline Academic & $\begin{array}{c}1.031 \\
(0.618)\end{array}$ & $\begin{array}{r}0.950 \\
(0.439)\end{array}$ & $\begin{array}{c}1.259 \\
(0.001)\end{array}$ & $\begin{array}{r}1.210 \\
(0.004)\end{array}$ \\
\hline High School & $\begin{array}{l}1.202 \\
(0.002)\end{array}$ & $\begin{array}{c}1.142 \\
(0.040)\end{array}$ & $\begin{array}{l}1.308 \\
(0.000)\end{array}$ & $\begin{array}{c}1.273 \\
(0.000)\end{array}$ \\
\hline Elementary school & ref. & ref. & ref. & ref. \\
\hline Sample size & 14,955 & 12,372 & 15,648 & 13,165 \\
\hline Pseudo $\mathrm{R}^{2}$ & 0.104 & 0.105 & 0.144 & 0.126 \\
\hline
\end{tabular}


Notes: 1. Stata 10 was used for estimation of country Fixed-Effects Logistic regressions.

2. p-values (significance levels) in parentheses.

3. To save space we present results for the whole sample only. Results of the European sample are not very different and can be provided by the authors upon request.

As is evident from Table 3, the use of country Fixed-Effects instead of country-specific explanatory variables (in Table 1) results in similar odds-ratio estimates and Hypotheses 2-5 are supported by these regressions too.

Hypotheses 2-5 are supported also by our 'rare prayer' logistic equations: these 2 aspects of secularization ('rare mass-attendance' and 'rare prayer') are similarly affected by exposure to religiosity during childhood. The effects of a religious mother/father and a religiously homogamous family are very similar. Own church attendance around the age of 12 tends to have a stronger negative effect on current prayer habits than on current church attendance (for both women and men).

Age has a stronger negative effect on 'rare prayer' - the probability of 'rare prayer' decreases constantly with age, for both women and men. The effect of education is also more pronounced: higher education (above elementary school) increases the probability of 'rare prayer' for both women and $\operatorname{men}^{37}$.

\section{Summary and concluding remarks}

In this paper we studied the evolutionary process of secularization. A simple theoretical model of cultural transmission and simulations were employed in order to examine the effects of oblique and direct religious socialization on the evolution of the secular and religious shares within the general population. Estimation of 'Secularization Equations', using ISSP (1998) data, indicated that (i) direct religious socialization efforts of one generation have a negative effect on secularization within the next generation; (ii) oblique socialization by the community has a parabolic effect on secularization; and (iii) the two

\footnotetext{
37 The effect of academic education on 'rare mass-attendance' is insignificant, most probably, because church attendance has also a networking positive effect for highly educated individuals that nets out the negative effect that high education is claimed to have on secularization. The networking effect is irrelevant for prayer intimate/private habits and therefore we observe a negative effect of high education.
} 
types of socialization are complements in the production of religiosity within the children's generation.

The theoretical model assumes that the religious make-up of the community where the individual lives is exogenous. In other words, the individual does not choose where to live. However, location is in many cases a choice variable. In particular, minority groups (e.g. immigrants) prefer to live in communities that share common traits (such as religion, religiosity and language) as a buffer against oblique socialization by the majority. The relation between location choices, cultural transmission and secularization is a subject yet to be investigated. 


\section{References:}

Ai, C. and Norton, E.C. (2003), "Interaction Terms in Logit and Probit Models," Economics Letters 80: 123-129.

Alesina, A. and Spolaore, E. (1997), "On the Number and Size of Nations," The Quarterly Journal of Economics 112(4): 1027-1056.

Amin, S., Diamond, I. and Steele, F. (1997), "Contraception and Religiosity in Bangladesh," in: Jones, G.W., Douglas, R.M., Caldwell, J.C. and D'Souza, R.M. (eds.), The Continuing Demographic Transition. Oxford: Clarendon Press: 268-289.

Azzi, C. and Ehrenberg, R. (1975), "Household Allocation of Time and Church Attendance," Journal of Political Economy 83: 27-56.

Bailey, E. (1998), “'Implicit Religion': What Might that Be?” Implicit Religion 1: 9-22.

Barro, R.J. and McCleary, R.M. (2005), "Which Countries Have State Religions?" Quarterly Journal of Economics 120(4): 1331-1370.

Becker, G.S. (1960), "An Economic Analysis of Fertility," in: Demographic and Economic Change in Developed Countries, Becker, G.S. (ed.). Princeton, NJ: Princeton University Press.

Becker, G.S, and Barro, R.J. (1988), "A Reformulation of the Economic Theory of Fertility," Quarterly Journal of Economics 103: 1-25.

Becker, G.S. and Lewis, H.G. (1973), "On the Interaction between the Quantity and Quality of Children," Journal of Political Economy 81: S279-S288.

Becker, G.S., Murphy, K.M. and Tamura, R. (1990), "Human Capital, Fertility and Economic Growth," Journal of Political Economy 98(5): S12-S37.

Becker, G.S. and Tomes, N. (1976), "Child Endowments and the Quantity and Quality of Children," Journal of Political Economy 84(4) Part 2: S143-S162.

Beit-Hallahmi, B. (1997), "Biology, Density and Change: Women's Religiosity and Economic Development," Journal of Institutional and Theoretical Economics 153: 166178.

Bisin, A. and Verdier, T. (2000), "Beyond the Melting Pot: Cultural Transmission, Marriage, and The Evolution Of Ethnic And Religious Traits," The Quarterly Journal of Economics 115(3): 955-988.

Bisin, A. and Verdier, T. (2001a), "The Economics of Cultural Transmission and the Dynamics of Preferences, " Journal of Economic Theory 97: 298-319.

Bisin, A. and Verdier, T. (2001b), "Agents with Imperfect Empathy may Survive Natural Selection,“ Economics Letters 71: 277-285.

Bisin, A., Topa, G. and Verdier, T. (2004), "Religious Intermarriage and Socialization in the United States," Journal of Political Economy 11(3): 615-664.

Black, S.E., Devereux, P.J. and Salvanes, K.G. (2005), "Why the Apple Doesn't Fall Far: Understanding the Intergenerational Transmission of Human Capital," American Economic Review 95(1): 937-949. 
Blau, F.D. (1992), "The Fertility of Immigrant Women: Evidence from High Fertility Source Countries," in: Borjas, G.J. and Freeman, R. (eds.), Immigration and the Work Force: Economic Consequences for the United States and Source Areas. Chicago: University of Chicago Press: 93-133.

Booth, A. and Kee, H.J. (2009), "Birth Order Matters: The Effect of Family Size and Birth Order on Educational Attainment," Journal of Population Economics 22(2): 367397.

Borooah, V.K. (2004), "The Politics of Demography: A Study of Inter-Community Fertility Differences in India," European Journal of Political Economy 20: 551-578.

Boyd, R. and Richerson, P. (1985), Culture and the Evolutionary Process. Chicago IL: University of Chicago Press.

Brañas-Garza, P. and Neuman, S. (2004), "Analyzing Religiosity within an Economic Framework: The Case of Spanish Catholics," Review of Economics of the Household 2(1): 5-22.

Brañas-Garza, P., and Neuman, S. (2006), "Intergenerational Transmission of 'Religious Capital': Evidence from Spain,” IZA (Bonn): Discussion Paper No. 2183.

Brañas-Garza, P. and Neuman, S. (2007), "Parental Religiosity and Daughters' Fertility: The Case of Catholics in Southern Europe," Review of Economics of the Household 5(3): 305-327.

Breault, K.D. (1989a), "New Evidence on Religious Pluralism, Urbanism, and Religious Participation," American Sociological Review 54(6): 1048-1053.

Breault, K.D. (1989b), "A Re-Examination of the Relationship between Religious Diversity and Religious Adherents: Reply to Finke and Stark," American Sociological Review 5: 1056-1059.

Buchanan, J.M. and Faith, R.L. (1987), "Secession and the Limits of Taxation: Towards a Theory of Internal Exit," The American Economic Review 77(5): 1023-1031.

Cavalli-Sforza, L. L. and Feldman, M.W. (1973), "Cultural versus Biological Inheritance: Phenotypic Transmission from Parent to Children," American Journal of Human Genetics 25: 618-637.

Cavalli-Sforza, L.L. and Feldman, M.W. (1981), Cultural Transmission and Evolution: A Quantitative Approach. Princeton, NJ: Princeton University Press.

Chaves, M. (1989), "Secularization and Religious Revival: Evidence from US Church Attendance Rates, 1972-1986," Journal for the Scientific Study of Religion 28: 464-477.

Cipriani, M., Giuliano, P. and Jeanne, O. (2007), "Like Mother Like Son? Experimental Evidence on the Transmission of Values from Parents to Children," IZA: Bonn, DP No. 2768.

Clark, C.A. and Worthington, A. (1987), "Family Variables Affecting the Transmission of Religious Values from Parents to Adolescents: A Review," Family Perspective 21: 121. 
Cornwall, M. (1988), "The Influence of Three Agents of Religious Socialization," In: Religion and Family Connection: Social Science Perspectives, Darwin, L.T. (ed.). Provo, UT: Brigham Young University Press.

Davis, J.A. and Smith, T.W. (1998), General Social Surveys, 1972-1998. Chicago: National Opinion Research Centre.

de-la Croix, D. and Michel, P. (2002), A Theory of Economic Growth: Dynamics and Policy in Overlapping Generations. Cambridge: Cambridge University Press.

Dohmen, T., Falk, A., Huffman, D. And Sunde, U. (2006), "The Intergenerational Transmission of Risk and Trust Attitudes," IZA (Bonn): Discussion Paper No. 2380.

Durkheim, E. (1995), Elementary Forms of Religious Life, translated by Fields, K.E. New York: free Press.

Erickson, J. A. (1992), "Adolescent Religious Development and Commitment: A Structural Equation Model of the Role of Family, Peer Group, and Educational Influences," Journal for the Scientific Study of Religion 31: 131-152.

Ermisch, J.F. (2003), An Economic Analysis of Fertility. Princeton, NJ: Princeton University Press.

Fan, C.S. (2008), "Religious Participation and Children's Education: A Social Capital Approach," Journal of Economic Behavior and Organization 65: 303-317.

Fernandez, R and Fogli, A. (2006), "Fertility: The Role of Culture and Family Experience," Journal of the European Economic Association 4(2-3): 552-561.

Fernandez, R and Fogli, A. (2009), "Culture: An Empirical Investigation of Beliefs, Work and Fertility," American Economic Journal 1(1): 146-177.

Finke, R. (1992), "An Un-secular America," In: Bruce, S. (ed.). Religion and Modernization. Oxford, England: Clarendon Press. Pp. 145-169.

Finke, R. and Stark, R. (1988), "Religious Economies and Sacred Canopies, Religious Mobilization in American Cities, 1906," American Sociological Review 53: 41-49.

Finke, R. and Stark, R. (1989), "Evaluating the Evidence: Religious Economies and Sacred Canopies," American Sociological Review 54: 1054-1056.

Franck, R. and Iannaccone, L.R. (2009), "Why Did Religiosity Decrease in the Western World during the Twentieth Century?", Bar-Ian University, mimeo.

Galor, O. and Moav, O. (2002), "Natural Selection and the Origin of Economic Growth," Quarterly Journal of Economics 117(4): 1133-1191.

Galor, O. and Weil, N.D. (2000), "Population, Technology, and Growth: From Malthusian Stagnation to the Demographic Transition and Beyond," The American Economic Review 90(4): 806-828.

Gill, A. and Lundsgaarde, E. (2004), "State Welfare Spending and Religiosity: A Cross National Analysis," Rationality and Society 16(4): 399-436.

Guinnane, T.W., Moehling, C.M. and O'Grada, C. (2006), "The Fertility of the Irish in the United States in 1910," Explorations in Economic History 43(3): 465-485. 
Hamilton, L.C. (2004), Statistics with Stata, London: Thomson Learning: 262-287.

Hanushek, E.A. (1992), "The Trade-off between Child Quantity and Quality," Journal of Political Economy 100(1): 84-117.

Hayes, B. C. and Pittelkow, Y. (1993), "Religious Belief, Transmission, and the Family: An Australian Study," Journal of Marriage and the Family 55: 755-766.

Heaton, T. (1986), "How Does Religion Influence Fertility? The Case of Mormons," Journal for the Scientific Study of Religion 28: 283-299.

Hoge, D.R., Petrillo, G.H. and Smith, E.I. (1982), "Transmission of Religious and Social Values from Parents to Teenage Children," Journal of Marriage and the Family 44: 569580.

Hungerman, D.M. (2009), "Crowd-out and Diversity," Journal of Public Economics 93: 729-740.

Iannaccone, L.R. (1990), "Religious Practice: A Human Capital Approach," Journal for the Scientific Study of Religion 29: 297-314.

Iannaccone, L.R. (1991), "The Consequences of Religious Market Structures: Adam Smith and the Economics of Religion," Rationality and Society 3: 156-177.

Iannaccone L.R. (1998), "Introduction to the Economics of Religion," Journal of Economic Literature 36: 1465-1495.

Iannaccone, L.R. (2003), "Looking Backward: A Cross-National Study of Religious Trends," Center for Study of Public Choice, George Mason University, mimeo.

Kelley, D.M. (1977), Why Conservative Churches are Growing: A Study on the Sociology of Religion. New York: Harper \& Row.

Knodel, J.E. (1974), The Decline of Fertility in Germany, 1871-1939. Princeton University Press.

Krugman, P. (1991), "Increasing Returns and Economic Geography," Journal of Political Economy 99(3): 483-499.

Landes, D. (2000), "Culture Makes almost all the Difference, In: Huntington, S.P., and Harrison, L.E. (eds.), Culture Matters: How Values Shape Human Progress. New-York: Basic Books, pp. 2-13.

Lehrer, E.L. (1996), "Religion as a Determinant of Marital Fertility," Journal of Population Economics 9: 173-196.

Lieberson, S. (1969), "Measuring Population Diversity," American Sociological Review 34: $850-862$.

Long, J. and Ferrie, J. (2005), "A Tale of Two Labor Markets: Intergenerational Occupational Mobility in Britain and in the U.S. since 1850," NBER WP No. 11,253

Loveland, M.T. (2003), "Religious Switching: Preference Development, Maintenance, and Change," Journal for the Scientific Study of Religion 42(1): 147-157.

McCleary, R.M. and Barro, R.J. (2006), "Religion and Political Economy in an International Panel," Journal for the Scientific Study of Religion 45(2): 149-175. 
Mitchell, M.N. and Chen, X. (2005), "Visualing Main effects and Interactions for Binary Logit Models," The Stata Journal 5(1): 64-82.

Morgan, S., Stash, S., Smith H.L. and Mason, K.O. (2002), "Muslim and Non-Muslim Differences in Female Autonomy and Fertility: Evidence from Four Asian Countries," Population and Development Review 28(3): 515-537.

Mosher, W. and Hendershot, G. (1984), "Religion and Fertility: A Replication," Demography 21(2): 185-191.

Mulligan, C.B. (1997), Parental Priorities and Economic Inequality. Chicago: Chicago University Press.

Mulligan, C.B. (1999), "Galton Versus the Human Capital Approach to Inheritance," Journal of Political Economy 107(6): 184-224.

Murphy, M. and Knudsen, L.B. (2002), "The Intergenerational Transmission of Fertility in Contemporary Denmark: The Effect of the Number of Siblings (Full and Half), Birth Order and Whether Male or Female," Population Studies 56(3): 235-248.

Neuman. S. (1986), "Religious Observance within a Human Capital Framework: Theory and Applications," Applied Economics: 1193-1203.

Neuman, S. (2007), “Is Fertility Indeed Related to Religiosity," Population Studies 61(2): 219-224.

Neuman, S. and Ziderman, A. (1986), "How Does Fertility Relate to Religiosity: Survey Evidence from Israel," Sociology and Social Research 70(2): 178-180.

Norton, E.C., Wang, H. and Ai, C. (2004), "Computing Interaction Effects and Standard Errors in Logit and Probit Models," The Stata Journal 4 (2): 154-167.

Olsen, D.V.A. (1999), "Religious Pluralism and US Church Membership: A Reassessment," Sociology of Religion 60(2): 149-173.

Ozorak, E.W. (1989), "Social and Cognitive Influences on the Development of Religious Beliefs and Commitment in Adolescence," Journal for the Scientific Study of Religion 28: 448-463.

Sacerdote, B. and Glaeser, E.L. (2001), "Education and Religion," Cambridge, MA: NBER, DP \#8080.

Sander, W. (1992), "Catholicism and the Economics of Fertility," Population Studies 46: 477-489.

Sandomirsky, S. and Wilson, J. (1990), "Processes of Disaffiliation: Religious Mobility among Men and Women," Social Forces 68: 1211-1229.

Schellekens, J. and van Poppel, F. (2006), "Religious Differentials in Marital Fertility in The Hague," Population Studies 60(1): 23-38.

Sherkat, D.E. (1991), "Leaving the Faith: Testing Theories of Religious Switching Using Survival Models," Social Science Research 20: 171-187. 
Sherkat, D.E, and Wilson J. (1995), "Preferences, Constraints, and Choices in Religious Markets: An Examination of Religious Switching and Apostasy," Social Forces 79:9931026.

Shy, O. (2007), "Dynamic Models of Religious Conformity and Conversion: Theory and Calibrations," European Economic Review 51: 1127-1153.

Solon, G. (1992), "Intergenerational Income Mobility in the United States," American Economic Review 82(3): 393-408.

Sommerville, C.J. (1998), "Secular Society/Religious Population: Our Tacit Rules for Using the Term 'Secularization'," Journal for the Scientific Study of Religion 37(2): 249253.

Swatos, W.H. and Christiano, K.J. (1999), "Secularization Theory: The Course of a Concept," Sociology of Religion 60(3): 209-228.

Tschannen, O. (1991), “The Secularization Paradigm: A Systematization," Journal for the Scientific Study of Religion 30: 395-415.

Thomson, E., McLanahan, S. and Curtin, R.B. (1992), "Family Structure, Gender, and Parental Socialization," Journal of Marriage and the Family 54: 368-378.

Tournemaine, F. (2008), "Social Aspirations and Choice of Fertility: Why Can Status Motive Reduce Per-Capita Growth?" Journal of Population Economics 21(1): 49-66.

Voas, D. (2003), "Intermarriage and the Demography of Secularization," British Journal of Sociology 54(1):83-108.

Warner, R.S. (1993), "Work in Progress for a New Paradigm for the Sociological Study of Religion in the United States," American Journal of Sociology 98: 1044-1093.

Weber, M. (1930), The Protestant Ethic and the Spirit of Capitalism. London, England: Allen and Unwin. 


\section{APPENDIX A:}

The second order conditions specify that $n_{t}^{i}$ and $d_{t}^{i}$ that were derived from the first order conditions (equations (4) and (5)) are maximizing the parent's utility:

$$
\begin{aligned}
& \frac{\partial^{2} u_{t}^{i}}{\partial\left(n_{t}^{i}\right)^{2}} \equiv \Omega_{11}=k^{i}\left(f^{i}\left(n_{t}^{i}\right)\right)^{\prime \prime} \\
& \frac{\partial^{2} u_{t}^{i}}{\partial^{2} d_{t}^{i}} \equiv \Omega_{22}=-n_{t}^{i}\left(\psi^{i}\left(d_{t}^{i}\right)\right)^{\prime \prime} \\
& \frac{\partial^{2} u_{t}^{i}}{\partial n_{t}^{i} \partial d_{t}^{i}}=\frac{\partial^{2} u_{t}^{i}}{\partial d_{t}^{i} \partial n_{t}^{i}} \equiv \Omega_{12}=\left[\left(1-q_{t}^{i}\right)\left(V^{i i}-V^{i j}\right)\right]-\left(\psi^{i}\left(d_{t}^{i}\right)\right)^{\prime}
\end{aligned}
$$

Since $\Omega_{11}<0$ (due to deceasing marginal utility); $\Omega_{22}<0$ (increasing marginal cost); and $\Omega_{12}=0$ (first order condition in (4)), we arrive at: $\Omega \equiv \Omega_{11} \Omega_{22}-\left[\Omega_{12}\right]^{2}>0$, proving that the critical point defined by the first order conditions is indeed maximizing utility. 
APPENDIX B

Table B1: Sample Characteristics, ISSP 1998.

\begin{tabular}{|c|c|c|c|c|}
\hline & \multicolumn{2}{|c|}{ All countries } & \multicolumn{2}{|c|}{ Europe } \\
\hline & Female & Male & Female & Male \\
\hline \multicolumn{5}{|l|}{ DEPENDENT VARIABLE } \\
\hline Secular (low religious practice) (\%) & 43.6 & 51.9 & 43.3 & 52.6 \\
\hline \multicolumn{5}{|l|}{ INDEPENDENT VARIABLES } \\
\hline Childhood experience (\%) & & & & \\
\hline $\begin{array}{r}\text { Religious father (attended church } \\
\text { services intensively) }\end{array}$ & 33.4 & 32.9 & 32.0 & 31.5 \\
\hline $\begin{array}{r}\text { Religious mother (attended church } \\
\text { services intensively) }\end{array}$ & 42.0 & 41.3 & 42.0 & 41.3 \\
\hline $\begin{array}{r}\text { Religious respondent at } 12 \text { (attended } \\
\text { church services intensively) }\end{array}$ & 49.1 & 44.3 & 49.7 & 44.3 \\
\hline Religious homogeneous household & 82.4 & 83.1 & 83.5 & 84.1 \\
\hline \multicolumn{5}{|l|}{ Marital Status } \\
\hline Married (\%) & 58.8 & 64.7 & 57.9 & 64.4 \\
\hline Married, spouse has 'no religion' (\%) & 8.8 & 7.8 & 8.6 & 7.5 \\
\hline Number of people in house. & $3.1(1.7)$ & $3.2(1.7)$ & $3.0(1.6)$ & $3.1(1.5)$ \\
\hline \multicolumn{5}{|l|}{ Age in years (\%) } \\
\hline $46-$ to- 59 & 21.5 & 23.3 & 21.5 & 22.9 \\
\hline $31-$ to- 45 & 31.0 & 30.7 & 30.5 & 30.3 \\
\hline 30 and under & 24.5 & 24.2 & 23.9 & 23.9 \\
\hline \multicolumn{5}{|l|}{ Education: last school attended (\%) } \\
\hline High School & 39.4 & 40.7 & 39.1 & 41.1 \\
\hline Elementary school & 21.4 & 18.2 & 23.2 & 19.6 \\
\hline Sample size & 14,955 & 12,372 & 12,382 & 9,936 \\
\hline Distribution of Religion (\%) & \multicolumn{2}{|c|}{45.0} & \multicolumn{2}{|c|}{48.7} \\
\hline Jewish & \multicolumn{2}{|c|}{3.7} & \multicolumn{2}{|c|}{0.1} \\
\hline Moslem & \multicolumn{2}{|c|}{1.1} & \multicolumn{2}{|c|}{0.7} \\
\hline Protestant & \multicolumn{2}{|c|}{17.3} & \multicolumn{2}{|c|}{19.9} \\
\hline Orthodox & \multicolumn{2}{|c|}{7.0} & \multicolumn{2}{|c|}{8.4} \\
\hline Others & \multicolumn{2}{|c|}{7.8} & \multicolumn{2}{|c|}{3.9} \\
\hline
\end{tabular}




\begin{tabular}{|c|c|c|c|}
\hline & All countries & \multicolumn{2}{|c|}{ Europe } \\
\hline & \begin{tabular}{l|l} 
Female & Male \\
\end{tabular} & Female & Male \\
\hline None & 18.1 & \multicolumn{2}{|c|}{18.3} \\
\hline Country Variables & $16,078(11,104)$ & \multicolumn{2}{|c|}{$15,226(10,705)$} \\
\hline Pluralism Index & $0.377(0.243)$ & \multicolumn{2}{|c|}{$0.351(0.238)$} \\
\hline
\end{tabular}

